\title{
Genome-wide analysis of Claviceps paspali: insights into the secretome of the main species causing ergot disease in Paspalum spp
}

\author{
H. Oberti', G. Spangenberg ${ }^{2,3}$, N. Cogan ${ }^{2,3}$, R. Reyno ${ }^{4}$, M. Feijoo $^{5}$, S. Murchio ${ }^{1}$ and M. Dalla-Rizza ${ }^{1 *}$ (D
}

\begin{abstract}
Background: The phytopatogen Claviceps paspali is the causal agent of Ergot disease in Paspalum spp., which includes highly productive forage grasses such as P. dilatatum. This disease impacts dairy and beef production by affecting seed quality and producing mycotoxins that can affect performance in feeding animals. The molecular basis of pathogenicity of C. paspali remains unknown, which makes it more difficult to find solutions for this problem. Secreted proteins are related to fungi virulence and can manipulate plant immunity acting on different subcellular localizations. Therefore, identifying and characterizing secreted proteins in phytopathogenic fungi will provide a better understanding of how they overcome host defense and cause disease. The aim of this work is to analyze the whole genome sequences of three C. paspali isolates to obtain a comparative genome characterization based on possible secreted proteins and pathogenicity factors present in their genome. In planta RNA-seq analysis at an early stage of the interaction of $C$. paspali with P. dilatatum stigmas was also conducted in order to determine possible secreted proteins expressed in the infection process.

Results: C. paspali isolates had compact genomes and secretome which accounted for $4.6-4.9 \%$ of the predicted proteomes. More than 50\% of the predicted secretome had no homology to known proteins. RNA-Seq revealed that three protein-coding genes predicted as secreted have mayor expression changes during 1 dpi vs 4 dpi. Also, three of the first 10 highly expressed genes in both time points were predicted as effector-like. CAZyme-like proteins were found in the predicted secretome and the most abundant family could be associated to pectine degradation. Based on this, pectine could be a main component affected by the cell wall degrading enzymes of $C$. paspali.

Conclusions: Based on predictions from DNA sequence and RNA-seq, unique probable secreted proteins and probable pathogenicity factors were identified in C. paspali isolates. This information opens new avenues in the study of the biology of this fungus and how it modulates the interaction with its host. Knowledge of the diversity of the secretome and putative pathogenicity genes should facilitate future research in disease management of Claviceps spp.
\end{abstract}

Keywords: Biotroph, Comparative genomics, Effectors, Pathogenicity factors, In silico prediction

\footnotetext{
* Correspondence: mdallarizza@inia.org.uy

'Instituto Nacional de Investigación Agropecuaria (INIA). Unidad de

Biotecnología. Estación Experimental INIA Las Brujas, Ruta 48 km, 10 Canelones, Uruguay

Full list of author information is available at the end of the article
}

C C The Author(s). 2021 Open Access This article is licensed under a Creative Commons Attribution 4.0 International License, which permits use, sharing, adaptation, distribution and reproduction in any medium or format, as long as you give appropriate credit to the original author(s) and the source, provide a link to the Creative Commons licence, and indicate if changes were made. The images or other third party material in this article are included in the article's Creative Commons licence, unless indicated otherwise in a credit line to the material. If material is not included in the article's Creative Commons licence and your intended use is not permitted by statutory regulation or exceeds the permitted use, you will need to obtain permission directly from the copyright holder. To view a copy of this licence, visit http://creativecommons.org/licenses/by/4.0/. The Creative Commons Public Domain Dedication waiver (http://creativecommons.org/publicdomain/zero/1.0/) applies to the data made available in this article, unless otherwise stated in a credit line to the data. 


\section{Background}

About 59 species of Claviceps cause the ubiquitous ovary restricted ergot disease, [1] affecting over 600 monocot plants including forage and the main cereals. Claviceps paspali is the main source of ergot disease in Paspalum spp. [2-4]. This fungus behaves as a true biotroph during its infection in planta, although it can be easily grown in axenic culture [5]. The genus Paspalum includes important forage grasses. Some of them, such as $P$. dilatatum, has all the desired characteristics for adaptation to a climate change scenario, such as being highly productive, drought and grazing tolerant, and persistent [6-9]. Infection with Ergot results in quantitative/qualitative loses of seed production by seed replacement with the sclerotia of the fungus [10], and the production of tremorgenic mycotoxins like paspalitrem A and B [1, $10]$, which is toxic to feeding animals $[1,11,12]$. Susceptibility to Ergot disease has prevented some cultivars of the genus from reaching their maximum potential [13, 14], and its importance becomes crucial where beef and dairy production are based on natural pastures, like Uruguay and Argentina. The agronomic impact in these grasses are largely because of the lack of a reported effective genetic resistance in the genus while fungicides can only marginally control the disease $[15,16]$.

There are various mechanisms of pathogen virulence and a wide range of plant immune responses [17]. Colonization by biotrophic fungus like C. paspali with compatible interaction could be a complex cross-talk between pathogen-host. This cross-talk involves hundreds of secreted fungal molecules, including enzymes that inactivate antimicrobial compounds produced by the host [18, 19], plant cell wall-degrading enzymes (PCWDEs) [20], transporters for acquiring nutrients, effector proteins and small molecules [21], among others. The main function of extracellular proteins is to interact with the environment of a fungus which is of paramount importance for the interaction of a pathogen with its host [21-23]. Although plant pathogenic fungi can secrete a large number of proteins, only a small proportion of these have been characterized as pathogenicity factors [24]. Some of these are effectors expressed in planta that suppress plant defense response by modulating plant cellular metabolic pathways and signaling cascades, and interfering with recognition machinery like cell wall receptors [25-28]. Another reported function for effectors is to modulate plant physiology to accommodate fungal invaders and provide them with nutrients $[29,30]$. To recognize pathogens, hosts have evolved the receptor protein immunity system that identifies effectors and pathogen/microbe associated molecular patterns (PAMPs/MAMPs). Infected plants can then initiate first-line innate PAMP-triggered immunity (PTI) or second-line effector-triggered immunity (ETI). PTI is initially triggered by PAMP (chitin is the most common in fungi) on the cell surface [18, 31]. Effectors like LysM containing domains Slp1 of Magnaporthe oryzae [32] or Ecp6 of Cladosporium fulvum [33], could suppress PTI from interfering with the recognition mechanism. ETI involves the recognition of the secreted effector by resistance-mediating receptor proteins (R-proteins), which trigger a strong defense response [34]. This mechanism leads progressively to the formation of pathogenic races with differences in the effector repertory [35, 36]. These differences are due to loss or modifications of effectors that can avoid detection through the corresponding arsenal of R-genes in the host plant. Meanwhile, the modification of the effector repertory places a selection pressure on the host for the formation of new R-gene variants [37].

Fungi with highly plastic genomes provide genetic diversity that not only is important in host or environmental adaptations, but also in contributing to divergence and speciation, like happened in Claviceps genus with $C$. purpurea [38]. Single species genomics and comparative genomics are important tools to study fungi adaptation to occupy environmental niches through the acquisition, loss, or diversification of protein families like effectors [39]. The value of comparative genomics to study the evolution of pathogenesis and the discovery of novel virulence determinants has been proved in several plant pathogen fungi genus like Fusarium [40, 41], Botrytis [42, 43] and Rhizoctonia [44], among others. But, only a limited number of studies have been conducted to identify secreted protein genes and possible pathogenicity factors in Claviceps genus, all of them centered in $C$. purpurea. Lo Presti et al. [18] performed the first genome-wide in silico secretome analysis of the Claviceps species together with several other fungus with different lifestyles. These authors discovered a low proportion of PCWDEs and a high proportion of not known functional secreted proteins in all the Claviceps analyzed, as expected in the biotrophic lifestyle. The presence of several genes like cppg1/cppg2 [45], cptf1 [46], cpmk1 and cpmk2 [47], involved in C. purpurea pathogenicity were detected, but none of them have been reported in C. paspali. Despite the availability of sequenced Claviceps spp. genomes and protein data, no expression data had been reported for C. paspali. There is no knowledge of the genes involved in causing disease, how it avoids necrosis or hypersensitive response in its host, or how it maintains its host's cell viability to obtain nutrients from living tissue [23, 48-50].

Specialized Claviceps genes involved in host-pathogen interactions such as host-specific effectors, elicitors, or Avirulence genes are undefined. Understanding C. paspali evolution is critical and valuable not only for predicting and monitoring the population changes but also for developing cultivars with durable resistance [51]. The 
use of functional genomics that use well-characterized effectors for the detection of R-genes in plant germplasm for the production of cultivars with long-lasting resistance is becoming increasingly common [35-37], and this could be used in C. paspali resistance.

Here, we used in silico prediction to identify possible secreted proteins and pathogenicity factor-like proteins present in the genomes of three isolates of $C$. paspali belonging to different lineages $[52,53]$ within the section Paspalorum [1]. Then, we used in planta RNA-seq during the early stages of infection of a $P$. dilatatum susceptible cultivar by $C$. paspali to pinpoint the expressed secretome. Since the related pathogens might differ in their secretome mainly by gene gain/loss or by rapid evolution of shared pathogenicity factors, we compared the full set of predicted secreted proteins of C. paspali with two other Claviceps species (C. purpurea and $C$. fusiformis) that are closely related but have completely different plant hosts. The analysis of secreted and pathogenicity factor-like proteins encoded in the genome should help to understand how the fungus manages to avoid plant defense response leading to pathogen perpetuation without killing the host (47). In turn, this would be useful for the identification of resistant counterparts in Paspalum spp. and for designing efficient strategies against this poorly characterized pathogen.

\section{Results}

\section{Genome assembly and annotation of ILB432 and ILB388} genome

C. paspali ILB388 isolate from $P$. plicatulum belongs to a separate lineage from the previously sequenced $C$. paspali isolates [53, 54]. The newly sequenced ILB388 has a larger genome than previously reported for C. paspali genome and slight difference in GC content and repeated sequences (Table 1). Based on a Chi-square test, differences between GC content was not significant $(p<.01)$ between isolates. Null hypothesis was mean GC content of isolates, and chi-square statistic was 0.0267 and $p$-value .986741 . A BUSCO assembly completeness analysis on 3156 orthologous genes for Ascomycota recovered 98.7, 98.4 and $96.9 \%$ single copy orthologues in genome assembly for ILB432, ILB388 and RRC-1481 respectively.

For the integrated de novo gene prediction of the three C. paspali isolates, the FunGAP pipeline was used with default parameters, in a combination of ab initio predictions, assembled RNA-seq transcripts obtained from four plant-pathogen mixed libraries (Additional file S1), and proteins from three related Clavicipitaceae. An annotation summary is displayed in Table 2. A total of 8012, 8243 and 8122 high-confidence protein-coding genes were predicted for ILB388, ILB432 and RRC-1481 respectively.

\section{Prediction of encoded candidate secretome in Claviceps paspali isolates}

We identified a comprehensive set of probable secreted proteins (PSP) in C. paspali isolates causing Ergot in Paspalum spp. Combining prediction programs increase specificity but decrease sensitivity, meaning that false positives results are excluded, and true positives are lost [55]. Due to this fact, we intended to make a more stringent search to report the most probable PSP in the $C$. paspali isolates. Proteins predicted to have a signal peptide, with no GPI anchor and TM domain and no ER retention signal with a predicted subcellular localization as extracellular were classified as secreted. From the full set of proteins of C. paspali isolate RCC-1481, 437 of these were considered as PSP, 371 were predicted in isolate ILB388, and 407 in isolate ILB432. The three isolates ILB388, ILB432 and RRC-1481 presented a similar small proportion of PSP ranging from 4.6-4.9\% of the whole predicted proteome (Table 2).

Table 1 Comparison of genome assembly stats of Claviceps paspali isolates

\begin{tabular}{llll}
\hline Category & ILB388 & ILB432 & RRC-1481 \\
\hline Estimated genome size (Mb) & 29.2 & 28.9 & 28.9 \\
GC content (\%) & 49.4 & 47.8 & 48.0 \\
No. of contigs & 885 & 701 & 2304 \\
N $_{50}$ of contigs & 89,397 & 79,562 & 26,898 \\
No. of scaffolds (> 200 bp) & 586 & 352 & $\mathrm{n} / \mathrm{s}$ \\
Total length of scaffolds (bp) & $29,270,071$ & $28,980,376$ & $\mathrm{n} / \mathrm{s}$ \\
N $_{50}$ of scaffolds (bp) & 196,155 & 146,886 & $\mathrm{n} / \mathrm{s}$ \\
Longest scaffolds (bp) & 734,927 & 616,281 & $\mathrm{n} / \mathrm{s}$ \\
No. N's per 100 kb & 21.0 & 23.0 & 0.8 \\
BUSCO analysis & $98.4(\mathrm{~S}), 0.0(\mathrm{D}), 0.5(\mathrm{~F}), 1.1(\mathrm{M})$ & $98.7 \%(\mathrm{~S}), 0.0 \%(\mathrm{D}), 0.1 \%(\mathrm{~F}), 1.2 \%(\mathrm{M})$ & $96.9(\mathrm{~S}), 0.0(\mathrm{D}), 1.2(\mathrm{~F}), 1.9(\mathrm{M})$ \\
Repeat sequences (\%) & 23.00 & 22.34 & 22.39 \\
\hline
\end{tabular}

$\mathrm{S}=$ Complete single copy; $\mathrm{D}=$ Complete Duplicated; $\mathrm{F}=$ Fragmented; $\mathrm{M}=$ Missing; $\mathrm{n} / \mathrm{s}=$ non-scaffold assembly level. 
Table 2 Summary of genome annotation for Claviceps. paspali isolates

\begin{tabular}{llll}
\hline & ILB432 & ILB388 & RRC-1481 \\
\hline Total protein-coding genes & 8243 & 8012 & 8122 \\
Transcript length (avg / med) & $1593.6 / 1344.0$ & $1633.6 / 1389.0$ & $1587.3 / 1291.0$ \\
CDS length (avg / med) & $1395.9 / 1155.0$ & $1430.1 / 1186.5$ & $1384.1 / 1119.0$ \\
Protein length (avg / med) & $465.3 / 385.0$ & $476.7 / 395.5$ & $461.4 / 373.0$ \\
Exon length (avg / med) & $532.5 / 262.0$ & $539.4 / 271.0$ & $557.1 / 291.0$ \\
Intron length (avg / med) & $121.9 / 96.0$ & $123.3 / 97.0$ & $136.8 / 98.0$ \\
Spliced genes & $6141(74.5 \%)$ & $5924(73.94 \%)$ & $5584(68.75 \%)$ \\
Gene density (genes/Mb) & 284.43 & 273.73 & 280.32 \\
Number of introns & 13,367 & 13,229 & 12,057 \\
Number of introns per gene (med) & 2.0 & 2.0 & 2.0 \\
Number of exons & 21,610 & 21,241 & 20,179 \\
Number of exons per gene (med) & 2.0 & 2.0 & 2.0 \\
\hline
\end{tabular}

Comparison of functional annotations between encoded predicted secretome candidates in Claviceps paspali isolates

The predicted secreted proteins were further functional annotated based on comparisons with the $\mathrm{Nr}$ NCBI database. Among the 1212 total PSP a BLAST hit was obtained in 248 in ILB388, 269 in ILB432 and 234 in RRC-1481. Functional annotation of the three isolates showed that and only $27.5 \%$ could be annotated with Gene Ontology (GO) terms (121 in ILB388, 115 in ILB432 and 117 in RRC-1481). Also, only 31 in ILB432, 25 in ILB388 and 32 in RRC-1481 sequences could be mapped to the KEGG pathway database.

Statistical comparisons between functions predicted in the three isolates were performed using Fisher's exact test $(p<0.05)$ (Additional file S2). Hydrolase activity (GO: 0016787) was the most common molecular function of the predicted secretome for each C. paspali isolates. RRC1481 has the highest number of proteins with hydrolase activity (77), while ILB432 has the lowest number (18). The annotations of the PSP in the GO Biological Process domain were mainly related to carbohydrate metabolic processes (GO:0005976, GO:0000272, GO:0044262), where RRC-1481 had the highest number of proteins (35) and ILB388 and ILB432 the lowest (17). Annotations in the GO Cellular Component were mainly related to integral components of membrane (GO:0016021) in ILB432, to membrane (GO:0016020) in ILB388 and to extracellular region (GO:0005576) in RRC-1481. The three C. paspali isolates did not show significant differences in the percentage of genes in the total secretome in any of the categories of these GO domains.

\section{Identification of possible pathogenicity factors like proteins in Claviceps paspali isolates}

Fungal effectors often share certain sequence characteristics such as size, cysteine content, or small motifs identified in fungi. The small secreted proteins (SSP) comprise $65.7 \%$ of the ILB388 secretome, $64.5 \%$ in ILB432 and $67.3 \%$ in RRC-1481 (Table 2). Furthermore, the small rich cysteine proteins (SRCP) in the entire secretome were of $33.2 \%$ for ILB388, 32.0\% for ILB432 and $31.0 \%$ for RRC-1481. Intriguingly, 65\% (81 proteins), $65.6 \%$ (67 proteins) and $73.4 .9 \%$ (83 proteins) of the total SRCP in ILB388, RRC-1481 and ILB432 respectively, had no homology with proteins in the Nr NCBI database. We also used effector signature motifs such as the [YW] XC found in several fungal secretome as a criterion for mining effectors from the secretome of C. paspali isolates. We identified a total of 53, 63 and 55 proteins with reported fungal effector motifs, where the most abundant motif was $\mathrm{Y} / \mathrm{F} / \mathrm{WxC}$ in all the three isolates (Additional file S3). It was found in approximately $10 \%$ of the three C. paspali isolates PSP and in approximately $3 \%$ of the whole C. paspali isolates proteome (Additional file S3). This indicates a 3-fold enrichment of these motifs in PSP and was significant in relation to the complete protein dataset.

In summary, the dbCAN2 CAZyme annotation of the secretome identified 134. CAZyme-like proteins (45 in RRC-1481, 45 in ILB388 and 44 in ILB432) (Fig. 1A), representing 38 CAZyme families (Additional file S4). Only four families were isolate specific, CE5 in ILB432 and CE 3, GH 3, GH47 in isolate ILB388. Among all PSPs identified, at least 98 (33 in ILB388, 32 in ILB432 and 33 in RRC-1481) are suggested to be involved in the degradation of polysaccharides (Additional file S4). Also, the three families with the greater number of proteins in each isolate are predicted to be PCWDEs, these were GH16, GH28 and GH43.

In total, 72, 66, 81 PSP in ILB432, ILB388 and RRC1481 respectively were BLASTp searched against the Pathogen-Host Interaction (PHI) database, where there are proteins from other plant pathogenic fungi that are 

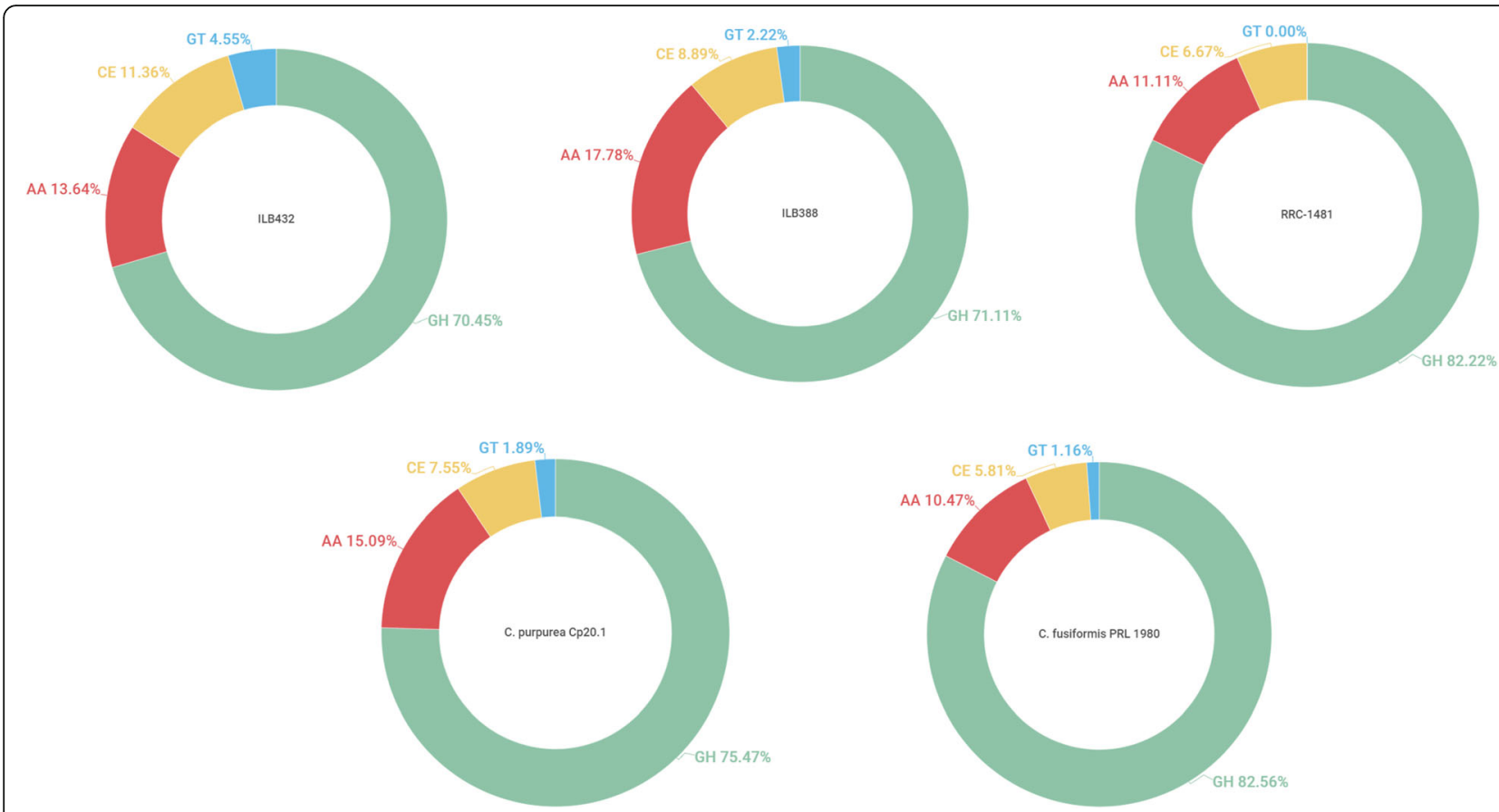

Fig. 1 Representation of CAZymes in Claviceps spp secretome. A percentage of CAZyme families in each isolate of Claviceps. GH=glycoside hydrolase; $\mathrm{AA}=$ Auxiliary Activities; $\mathrm{GT}=$ glycosyltransferase; $\mathrm{CE}=$ carbohydrate esterase

Table 3 Summary of prediction of secretome and pathogenicity related factors in Claviceps paspali isolates

\begin{tabular}{|c|c|c|c|}
\hline Category & ILB388 & ILB432 & RRC-1481 \\
\hline Total proteins & 8012 & 8243 & 8122 \\
\hline PSP (\% of total proteome) & $371(4.6 \%)$ & 409 (4.9\%) & $364(4.5 \%)$ \\
\hline PSP with BLAST results (\% total PSP) & $248(66.8 \%)$ & $269(65.8 \%)$ & $234(64.3 \%)$ \\
\hline PSP functional annotated (\% total PSP) & $121(32.6 \%)$ & $115(28.1 \%)$ & $117(32.1 \%)$ \\
\hline SSP & 244 & 264 & 245 \\
\hline Total SCRP & 123 & 127 & 113 \\
\hline Conserved effectors motifs & 53 & 63 & 55 \\
\hline Total PHI-base & 56 & 65 & 81 \\
\hline Total CAZymes & 45 & 54 & 45 \\
\hline Total effector like proteins (\% of total PSP) ${ }^{a}$ & $263(71.1 \%)$ & $292(71.4 \%)$ & $264(72.5 \%)$ \\
\hline Total predicted pathogenicity factors (\% of total PSP) ${ }^{\mathrm{b}}$ & $325(87.6 \%)$ & $353(86.3 \%)$ & $316(86.8 \%)$ \\
\hline \multicolumn{4}{|l|}{ Localization of predicted effectors } \\
\hline Apoplast ${ }^{c}$ & 230 & 239 & 223 \\
\hline Chloroplast $^{d}$ & 13 & 14 & 21 \\
\hline Mitochondria $^{d}$ & 12 & 18 & 8 \\
\hline Nucleus ${ }^{d}$ & 32 & 26 & 31 \\
\hline
\end{tabular}

${ }^{a}=$ Proteins with at least one condition defined for effector; ${ }^{b}=$ Proteins with at least one condition defined for pathogenicity factor prediction; ${ }^{c}=$ Predicted with ApoplastP; ${ }^{d}=$ Predicted with Localizer. PSP = predicted candidate secreted protein. SSP = small secreted protein. SCRP = small cysteine-rich protein 
involved in pathogenesis and modulate host responses. The predicted pathogenicity-associated genes recovered were classified into four of the nine categories based on the definition of phenotypes in the PHI database [56]. The results of the predictions are summarized in Table 3 and details are presented in Additional File S2. The categories indicating virulence factors, which are the most relevant, are "loss of pathogenicity", "reduced virulence" and "effectors". Most of the sequences are classified as reduced virulence in the three isolates (Additional File S2), and there is no significative difference between categories among C. paspali isolates.

The total proteins that were predicted as effector-like by any of the five approaches (PHI-base "effector" category was take into account) ranges between the $71.1 \%$ (ILB388), 85.4\% of the total secretome in ILB432 to $86.8 \%$ in RRC-1481, indicating that almost all the PSP of this species could be predicted as an effector. Of the predicted effector-like proteins, between 31.5 to $32.7 \%$ were encoded proteins with no BLAST results. A total of $7 \mathrm{GO}$ terms were over-represented based on Fisher exact test in ILB432 effector-like proteins, and no term was overrepresented in ILB388 and RRC-1481 (Additional File S2).

\section{Claviceps paspali repeat sequence content and association with predicted secretome}

The three C. paspali genomes comprised between 18,6 and $19 \%$ of interspersed repeated DNA sequences (Additional file S5). An analysis of the Transposable element (TE) revealed an overrepresentation of long terminal repeat (LTR) elements representing about $62 \%$ of the repetitive sequences in the three genomes.

TE identification was used to calculate the average distance (kbp) of each gene to the closest TE fragment on the $5^{\prime}$ and 3 ' flanking side (Additional file S5). This analysis was performed for both all PSP and non-PSP gene models. The mean gene TE distance was between 17,53 $\mathrm{kbp}$ in ILB432, 23,34 kbp in ILB388, while in PSP were between 15,15 kbp, 19,65 kbps respectively. Based on a Mann Whitney test using all non-PSP genes as control, we determined that PSP were significantly closer to TEs than non-PSP genes in the two analyzed $C$. paspali genomes. However, if we use the distance to LTR as sole input for evaluation, only in ILB432 PSP are significantly closer $(P<0.05)$ to LTR than non-PSP.

\section{Conservation of predicted secretome across Claviceps paspali isolates}

We determined the unique and conserved proteins across the secretome of $C$. paspali isolates. OrthoFinder was used to identify orthologs between the proteins of three predicted secretome. A set of 345 orthogroups was established for the C. paspali isolates, representing a total of 1139 proteins. A total of 234 orthogroups were set as the core secretome and only two orthogroups as isolate-specific (Additional file S6). There was a total of 26, 28 and 19 proteins of ILB388, ILB432 and RRC-1481 respectively that where not assigned to any orthogroups, that could be taken also as secretome isolate-specific proteins. ILB432 and RRC-1481 shared between them 46 orthogroups, ILB388 shared 48 with ILB432 and 15 with RRC-1481 (Fig. 2A). These results indicate that the core secretome in C. paspali represent more than $70 \%$ of the PSP orthogroups (Fig. 3A).

\section{Conservation of predicted secretome across Claviceps species}

We described the probable secretome of $C$. purpurea and C. fusiformis (Additional file S7) for comparison with the $C$. paspali PSP. For this comparison, a nonredundant secretome of $C$. paspali was obtained using the CD-HIT algorithm (95\% identity) to produce a final list of 729 unique proteins that represent the combined predicted secretome of the three isolates. This nonredundant predicted secretome was compared with the PSP of C. purpurea and C. fusiformis using OrthoFinder (Additional File S8), resulting in a total of 1614 proteins analyzed (Fig. 2B). For the Claviceps species secretome comparison, a total of 143 orthogroups present in all species (core secretome) and a total of 94 species-
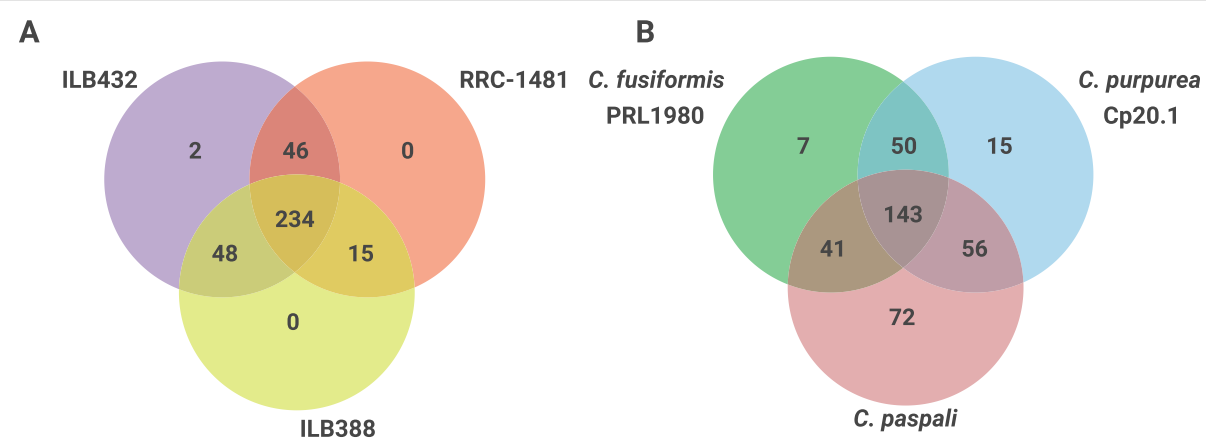

Fig. 2 Conservation of PSP based on OrthoFinder results. A Venn diagram showing the number of unique and shared orthogroups in C. paspali isolates (A) and across the three Claviceps species (B). Species-specific orthogroups are determinate by species-specific and unassigned orthogroups 
A

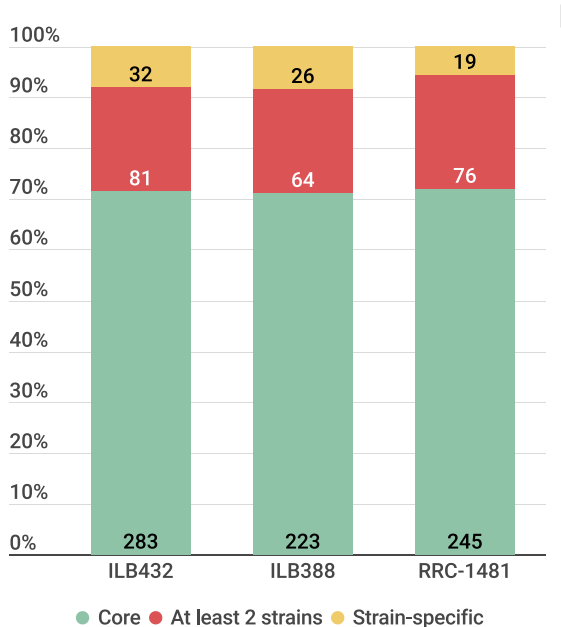

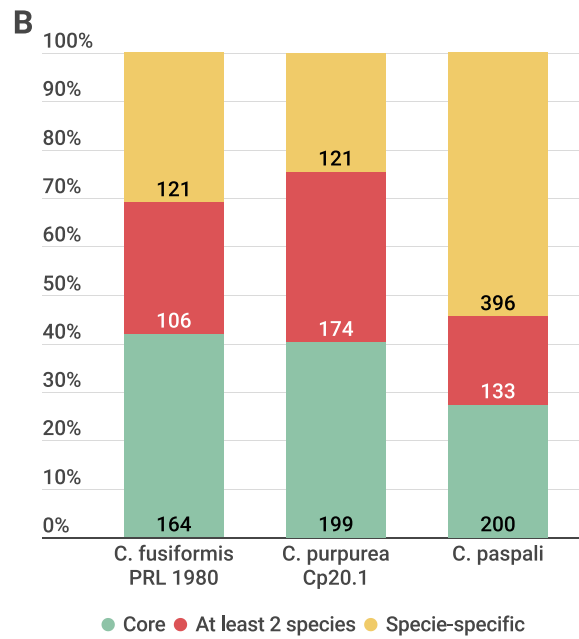

Fig. 3 Conservation of PSP based on OrthoFinder results. This figure shows the fraction based in the percentage of unique and conserved proteins within the complete PSP of C. paspali isolates (A) and across the three Claviceps species analyzed (B)

specific orthogroups (7 in C. fusiformis, 15 in C. purpurea and 72 in C. paspali) were found. Unassigned proteins were 77 (18.7\% of the secretome), $71(14.2 \%)$ and 69 (11\%) proteins in C. fusiformis, C. purpurea and C. paspali respectively. Interestingly, $54.3 \%$ of the secretome of C. paspali is unique (Fig. 3B). By contrast, the secretome of the two other Claviceps species have a smaller set of unique proteins and a higher set of conserved proteins. Only 30.9 and $24.4 \%$, of the secretome of $C$. fusiformis and C. purpurea respectively is unique (Fig. 3B).

\section{Transcriptomic analysis}

To investigate how the fungal genetic program is deployed during a host infection, we applied Illumina RNA sequencing to the $C$. paspali - P. dilatatum pathosystems. Transcriptomic data of two early time points of the fungal infection, 1 and $4 \mathrm{dpi}$, representing penetration and established infection respectively, were used to generate an overview of the in planta expressed portion of the secretome. Based on the fact that ILB432 has the least fractionated genome and belongs to the most common lineage of $C$. paspali affecting $P$. dilatatum, we used its draft genome to analyze the $C$. paspali PSP expressed in planta (Additional file S9). To analyze correlation between biological replicates across all conditions a clustering analysis was made (Additional file S10). Hierarchical cluster analysis shows that biological replicates of the same condition are cluster tightly, indicating the reproducibility and correlation between samples.

All genes with a TPM $>=1$ in all the replicates in each condition, were considered as expressed in a time point (Table 4). Also, expressed genes were grouped into three categories according to their main expression levels in each condition: low (1 to 10 TPM), medium (11 to 1000 TPM), high (more than 1000). Almost all the proteincoding gene models in $C$. paspali ILB432 were transcribed in planta in at least one time point (6861 genes, or $83.2 \%)$. In total, $326(78.7 \%)$ sequences of the PSP were expressed during at least one of the two time points, which is smaller than the percentage found for the whole proteome. At $1 \mathrm{dpi}$ is the time point where more PSP (321) and unique PSP are expressed (97). Also, about 30\% more predicted pathogenicity factors are expressed during $1 \mathrm{dpi}$ in comparison with 4dpi (Table 4). Approximately 72.9 and $76.2 \%$ of effector-like and pathogenicity factor-like proteins are expressed during $1 \mathrm{dpi}$, while 50.7 and $54.4 \%$ at $4 \mathrm{dpi}$. No significative differences were detected in PSP expression between conditions. Between the first 10 highly expressed genes in both time points evaluated (Additional file S9), 4 genes were PSP and predicted as effector-like, and three of these are shared between 1 and 4 dpi. The first two most expressed genes are the predicted effector-like CpILB432_gene_07899 and CPILB432_gene_07732. The

Table 4 Summary of expressed genes during 1 and 4 dpi based on the analysis of expression of RNA-seq mapped to the Claviceps. paspali ILB432 genome

\begin{tabular}{lllll}
\hline Condition & Total expressed genes & PSP & Predicted effector-like proteins & Predicted pathogenicity factors \\
\hline $1 \mathrm{dpi}$ & 6772 & 314 & 213 & 269 \\
$4 \mathrm{dpi}$ & 5492 & 227 & 148 & 192 \\
\hline
\end{tabular}


second most expressed at $4 \mathrm{dpi}$ is also CPILB432_gene 07899. None of these four predicted effector-like proteins has functional annotation or known PFAM domain. To allow for a broad and unbiased evaluation of the fungal transcriptome of these two time points during infection (penetration and colonization), an analysis of differential expression between 1 and 4 dpi conditions was made. Based on this analysis a total of 24 genes with higher expression were found between conditions. Of these, 21 were more expressed during $1 \mathrm{dpi}$, and three during $4 \mathrm{dpi}$ (Table 5). Three genes that were identified as PSP (CpILB432_gene 06873, CpILB432_gene 04049 and CpILB432_gene 03624), were more expressed during $1 \mathrm{dpi}$ and belong to the 5 genes with more FC with statistical significance $(\mathrm{FDR}<0.01)$ in this comparation. Gene CPILB432_gene_06873 was predicted as effector and SCRP, CpILB432_gene 04049 was also predicted as effector with [KRHQSA][DENQ] EL motif and CpILB432_gene 03624 was predicted as effector, SCRP and with motif [YW]XC.

Validation of gene expression by RT-qPCR was not done based on previous studies that shown extremely close correlation between RT-qPCR and RNA-seq results [57-61]. Also, our biological samples are highly similar within treatments and clearly distinct between treatments (Additional File S10).

\section{Discussion}

\section{Claviceps paspali genome}

This paper reports, for the first time, an analysis of whole genome sequences for multiple isolates of $C$. paspali assembled with short-reads. A high proportion (> 95\%) of single copy BUSCO genes were recovered showing a high completeness in all three analyzed genome assemblies. All C. paspali isolates had highly compact genomes, with sizes of $28-29 \mathrm{Mb}$. This is similar to other Claviceps spp. genomes, that range between 28.9 and $52.3 \mathrm{Mb}$ [54], but smaller than the average genome size of plant pathogenic ascomycetes $(39.4 \mathrm{Mb})$ [62]. Approximately $23 \%$, of the genome was repeated content, where TE was the most prominent family. This is similar to other fungi where TEs comprise1 to $25 \%$ of the genome [63].

We also annotated for the first-time a C. paspali genome using RNA-seq data. The genomes of the three $C$. paspali isolates were very similar regarding protein coding genes. The ILB432 and RRC-1481 genome assemblies were smaller than the ILB388 assembly. Even so, these differences in genome and TEs content are not significative and could represent a bias in sequencing technology. It is known that short reads could lead to subrepresentation of genome size problems by bad resolution of complex regions like repetitive gene sequences or transposable elements [64]. These issues could be solved with long-reads sequencing (like PacBio or Oxford Nanopore) and should be addressed in future in these species.

\section{The Claviceps paspali predicted secretome}

The repertoire of PSP of these C. paspali isolates helps understand the pathogenic process, due to their putative roles in penetration, host tissue degradation and host immunity subversion [18, 65-67]. Several studies have reported that the size of fungal secretome correlates with lifestyle [18, 68-70]. Furthermore, the types of secreted proteins during host infection depend on the pathogenic lifestyle of the fungus. Necrotrophic fungi secrete plant cell wall-degrading enzymes or toxins to kill their host cell, whereas biotrophic fungi like C. paspali secrete proteins to avoid or suppress host defense responses to keep their host cells alive thus maintaining a long-term feeding relationship [71]. The reported host range of C. paspali is at least 19 species of the Paspalum genus [4], but its secretome is about $4.5-4.9 \%$ of total proteome. This predicted secretome was in accordance with data from several other facultative biotrophs where approximately 5 to $10 \%$ of the proteome were PSP [18]. This suggests that the broad host species range was not achieved by acquiring many secreted proteins in C. paspali. Furthermore, small secretome may minimize the potential for triggering plant immunity following detection of secreted proteins [44].. Also, PSP in C. paspali could encoded about 400 novel proteins that lack of known functional domains and homology to known proteins, similar to other fungi with the same nutritional lifestyle $[18,70,72]$. These proteins could be involved in novel strategies specialized in both for infection and evasion of immunity in species of the genus Paspalum.

Similarities between these isolates in their relative abundances of functionally annotated genes could suggest a conserved infection strategy. Hydrolase activity (GO:0016787) was the most common molecular function of the predicted secretome for each C. paspali isolates, similar to secretomes in several pathogenic fungi [42, 69, 73], including C. purpurea-rye interactions [49].

It has been reported that PSP could be located in more repeat-rich regions and TE could be associated with the loss or gain of a particular gene responsible for rapid evolution, including gain and loss of pathogenicityrelated genes in these isolates [i.e: 84, 85, 97, 98]. In Claviceps genus there are reports of this in Claviceps and Pusillae sections [74]. Our data shows that TE are significantly close to PSP in the two analyzed C. paspali isolates. This difference between our report and previous reports for RRC-1481 [74] could be due the difference in structural annotations used for analysis and prediction method for PSP. Also, PSP in ILB432 (and not in ILB388) were found to be significantly closer to LTRs 
Table 5 Genes differentially expressed in ILB432 during 1 vs 4 dpi

\begin{tabular}{|c|c|c|c|c|}
\hline & Gene ID & BLAST Accession & $\log \mathrm{FC}$ & FDR \\
\hline \multirow[t]{21}{*}{1 dpi UP REGULATED } & CpllB432_gene_02158 & $\begin{array}{l}\text { CCE31305.1|related to major facilitator MirA } \\
\text { [Claviceps purpurea 20.1] }\end{array}$ & $-9,923,735,523$ & $7,14 \mathrm{E}-06$ \\
\hline & CplLB432_gene_05184 & $\begin{array}{l}\text { XP_018140586.1|Rad4 transglutaminase-like } \\
\text { domain-containing protein [Pochonia chlamydosporia 170] }\end{array}$ & $-975,031,661$ & 0,00020199 \\
\hline & CpllB432_gene_06873* & $\begin{array}{l}\text { CCE27092.1|uncharacterized protein } \\
\text { CPUR_00564 [Claviceps purpurea 20.1] }\end{array}$ & $-6,095,858,717$ & 0,0004902 \\
\hline & CplLB432_gene_03624 & $\begin{array}{l}\text { CCE27096.1|uncharacterized protein } \\
\text { CPUR_00568 [Claviceps purpurea 20.1] }\end{array}$ & $-5,991,756,785$ & 0,0004619 \\
\hline & CplLB432_gene_04049* & $\begin{array}{l}\text { CCE31699.1|uncharacterized protein } \\
\text { CPUR_05553 [Claviceps purpurea 20.1] }\end{array}$ & $-489,987,136$ & $5,74 \mathrm{E}-05$ \\
\hline & CplLB432_gene_06757 & $\begin{array}{l}\text { EWZ78380.1|hypothetical protein } \\
\text { FOWG_17350 [Fusarium oxysporum f. sp. lycopersici MN25] }\end{array}$ & $-3,892,808,943$ & $1,30 \mathrm{E}-08$ \\
\hline & CplLB432_gene_02058 & $\begin{array}{l}\text { CCE33483.1|probable SIT1-Transporter of the bacterial } \\
\text { siderophore ferrioxamine B [Claviceps purpurea 20.1] }\end{array}$ & $-3,679,279,939$ & $5,62 \mathrm{E}-10$ \\
\hline & CplLB432_gene_04875 & $\begin{array}{l}\text { XP_007813912.1|extracellular serine-rich protein } \\
\text { [Metarhizium acridum CQMa 102] }\end{array}$ & $-2,984,494,587$ & 0,00054842 \\
\hline & CplLB432_gene_05927 & $\begin{array}{l}\text { CCE30713.1/uncharacterized protein CPUR_04562 } \\
\text { [Claviceps purpurea 20.1] }\end{array}$ & $-2,937,451,378$ & 0,0004619 \\
\hline & CpllLB432_gene_03545 & $\begin{array}{l}\text { KDB16458.1|short-chain dehydrogenase/reductase } 2 \\
\text { [Ustilaginoidea virens] }\end{array}$ & $-2,875,735,595$ & $1,30 \mathrm{E}-08$ \\
\hline & CplLB432_gene_03512 & No Blast Hit & $-2,849,291,501$ & $5,36 \mathrm{E}-05$ \\
\hline & CplLB432_gene_05140 & XP_018140533.1|allergen [Pochonia chlamydosporia 170] & $-2,844,088,745$ & $5,55 \mathrm{E}-05$ \\
\hline & CplLB432_gene_02054 & $\begin{array}{l}\text { XP_007819099.2|hypothetical protein MAA_02910 } \\
\text { [Metarhizium robertsii ARSEF 23] }\end{array}$ & $-2,835,956,686$ & 3,27E-05 \\
\hline & CplLB432_gene_06755 & $\begin{array}{l}\text { CCE32677.1/uncharacterized protein CPUR_06541 } \\
\text { [Claviceps purpurea 20.1] }\end{array}$ & $-2,747,141,458$ & $6,99 \mathrm{E}-06$ \\
\hline & CplLB432_gene_00516 & $\begin{array}{l}\text { CCE29318.1|related to O-methylsterigmatocystin } \\
\text { oxidoreductase [Claviceps purpurea 20.1] }\end{array}$ & $-2,699,405,679$ & $5,36 \mathrm{E}-05$ \\
\hline & CpllLB432_gene_03325 & $\begin{array}{l}\text { KZZ93778.1|hypothetical protein AAL_05494 } \\
\text { [Moelleriella libera RCEF 2490] }\end{array}$ & $-2,679,797,919$ & 7,74E-05 \\
\hline & CplLB432_gene_07758 & $\begin{array}{l}\text { KHN97956.1|hypothetical protein MAM_04345 } \\
\text { [Metarhizium album ARSEF 1941] }\end{array}$ & $-2,359,145,346$ & $5,36 \mathrm{E}-05$ \\
\hline & CplLB432_gene_02316 & $\begin{array}{l}\text { KZZ94274.1|NAD(P)-binding domain protein } \\
\text { [Moelleriella libera RCEF 2490] }\end{array}$ & $-235,850,479$ & $5,55 \mathrm{E}-05$ \\
\hline & CplLB432_gene_00162 & No Blast Hit & $-2,266,379,409$ & 3,27E-05 \\
\hline & CplLB432_gene_08111 & $\begin{array}{l}\text { OAA32324.1|Thioredoxin-like protein } \\
\text { [Moelleriella libera RCEF 2490] }\end{array}$ & $-2,210,366,996$ & 0,00026004 \\
\hline & CplLB432_gene_02137 & $\begin{array}{l}\text { RZR60711.1|hypothetical protein } \\
\text { |1G_00000288 [Pochonia chlamydosporia 123] }\end{array}$ & $-1,993,353,249$ & 0,00041294 \\
\hline \multirow[t]{3}{*}{4 dpi UP REGULATED } & CpllLB432_gene_03143 & $\begin{array}{l}\text { CCE31647.1|uncharacterized protein } \\
\text { CPUR_05500 [Claviceps purpurea 20.1] }\end{array}$ & $212,350,458$ & $5,36 \mathrm{E}-05$ \\
\hline & CpllLB432_gene_03342 & No Blast Hit & $2,235,801,505$ & 0,00038791 \\
\hline & CplLB432_gene_02170 & $\begin{array}{l}\text { KFG81740.1|Amino-acid permease inda1 } \\
\text { [Metarhizium anisopliae] }\end{array}$ & $3,083,272,028$ & $5,06 \mathrm{E}-06$ \\
\hline
\end{tabular}

* $=$ predicted as PSP

compared with other genes. These differences could support the theory of differentiation of lineages in the C. paspali species. The proximity of LTR to secreted proteins might cause duplication or loss events that could lead to speciation in this lineage. Further research should be made into this matter to address this point.

\section{Approach to the effector-like proteins repertoire in Claviceps paspali species}

We identified a variable number of predicted effectorlike coding genes among $C$. paspali isolates using different criteria. During the penetration phase, $C$. paspali grows mainly intercellularly [2]. Unlike C. purpurea [75], C. paspali has not been documented to produce 
specialized intracellular structures, suggesting that interaction with the plant may be predominantly apoplastic. This was in consonance with our results: between 54 and $63 \%$ of the PSP were predicted as secreted to the apoplast with ApoplastP. Thus, C. paspali could be a fungal pathogen like Cladosporium fulvum, Zymoseptoria tritici, Leptosphaeria maculans and Venturia inaequalis, which colonize plants extracellularly and rely on effectors to target basal apoplastic host defense components [76, 77].

Reactive oxygen species, calcium oscillations and the synthesis of plant defense molecules, such as phytohormones, are produced in the chloroplast and are essential providers of redox resources to fight pathogen attacks. These functions are key in the early defense of the plant $[30,78]$. In our case, almost $11 \%$ of the total PSP in the three isolates were predicted to have an action in the chloroplast. Interestingly, no effector-like proteins were found to be involved in phytohormone synthesis and this is an aspect of study that should be further explored.

Within the fungal secretome, SSPs and SCRP have been widely studied for their role in pathogenesis, particularly functioning in the apoplast [18, 77, 79]. The three isolates of C. paspali had approximately 65 and $33 \%$ of SSP and SCRP respectively, more than the average SSP (52\%) and SCRP (23\%) contents in plant pathogen fungi [22] but similar to values obtained in biotrophs [70]. This gives weight to the theory that biotrophs encode more and more diverse effector-like SSPs to suppress host defense compared to necrotrophs, which generally use cell wall degrading enzymes and phytotoxins to kill hosts [18, 72, 80]. Approximately more than half of the SCRP in each isolate lack homology to proteins in other species, like was reported before for fungi and oomycete plant pathogens [18].

All searched for conserved effector motifs were present in C. paspali isolates PSP. Based on this search we identified that the motif [YFW] $\mathrm{xC}$ is the most abundant in the C. paspali PSP. This motif was first discovered in the barley powdery mildew obligate biotroph fungus Blumeria graminis [81] and later in rust fungi [82]. Typically, this motif is in close proximity to the signal peptide, but like with rust fungi, [82] this motif was found dispersed and no restricted to the $\mathrm{N}$-terminus in C. paspali isolates. The occurrence of this motif in PSP is more than three times higher compared to the whole proteome in C. paspali isolates. Based on this we suggest that this could be a useful motif for effector candidate prediction in C. paspali.

PSP, matched with known effectors in the PHI-base, were included in the set of effector-like candidates. In the three isolates there is a homologue of the LysM1 a Penicillium expansum effector protein. Effectors carrying LysM domain have been identified in numerous pathogenic fungi and their role in the first stages of infection has been established, based on chitin sequestration [83]. In C. purpurea, deletion of gene Cp8623, a LysM carring secreted protein, showed a decrease in virulence. Therefore, this type of protein could be important but not determinant in the development of Ergot disease.

\section{Plant cell wall degrading enzymes in the predicted secretome of Claviceps paspali}

Most biotrophic fungi degrade plant tissues by producing a set of enzymes specifically focused on plant polysaccharide degradation $[18,84]$. These are critical for pathogenicity because many of them break down the physical barrier to the host tissue, and their breakdown products include sugar monomers that could be food sources. Pectin (a polymer of mainly D-galacturonic acids) hydrolysis has been proved to be an important step for fungal penetration in monocots $[85,86]$. The fact that pollen tubes show pectinolytic activity [87], could be taken as evidence to the hypothesis that Claviceps species mimic pollen tube and adapt their lifestyle to the pollen tube/plant tissue system [5].

The relevance of pectin degradation for C. paspali colonization could be consistent with our findings where two of the CAZyme families with the highest number of genes were the GH28 ( 4 genes) and GH43 (4-5 genes) families. Both families could be associated to pectin degrading enzymes. A common match in the three isolates in the BLASTp against the PHI-base was the CPPG2 gene of $C$. purpurea that encodes a endopolygalacturonase involved in the degradation of the pectin present in the style and ovary tissue of rye [45], and a pectin methylesterase BCPME1 of Botrytis cinereal who also is a key virulence factor in this fungus [88]. This could lead to the conclusion that the C. paspali infection process is similar to the infection process of $C$. purpurea on rye flowers where in the early stages of infection pectin degradation and polygalacturonase activity represent a pathogenicity factor.

Also, the secretome of C. paspali contains enzymes involved in chitin degradation, which is an important component of the fungal cell wall, and one of the most studied molecules that activate plant defenses $[25,89]$. Based on BLASTp results to the PHI-base, in the three isolates there were PSP homologous proteins matching a known effector GH18 chitinase like CHT42 of Trichoderma virens.

\section{An approach to host speciation related to the predicted secretome in the Claviceps species}

The three analyzed species have completely different host ranges. While C. purpurea causes ergot of wheat, rye, barley, oats, and many other host species [90], $C$. 
fusiformis is restricted to pearl millet (Pennisetum glaucum) and buffel grass (Pennisetum ciliare) [15, 91], and C. paspali is a pathogen of grasses in the genus Paspalum [2]. It has been proposed that gene loss/gain were the hallmark of jump events to new hosts [92]. The unique and conserved proteins identified across the secretome of Claviceps species could lead to a better understanding of the important players for virulence and host specificity. Genome comparisons of C. paspali with the related Ergot causing fungi $C$. purpurea and $C$. fusiformis revealed that $27-43 \%$ are conserved PSP in three species sequenced so far and we call them core secretome.

Among the few functionally characterized pathogenicity factors in Ergot pathogens, the CPPG2 gene [45] was shared among all Claviceps species and might constitute a core virulence factor for the establishment of the disease or for enhancing pathogen fitness. All Ergot species analyzed had proteins in the orthogroup OG0000053, formed by orthologs of the CPPG2 gene. However, besides this enzyme, no other Claviceps spp. proved pathogenicity factor were part of the core secretome. Other characterized C. purpurea predicted secreted pathogenicity factor like CPPG1 [45] showed no shared orthologs in any of the C. fusiformis and C. paspali secretome. Species-specific PSP may explain the observed differences in host adaptation among species and isolates [42, 93]. However, the secretome of C. purpurea has the smallest fraction of unique proteins which is not in consonance to its broad host range of this species. This could suggest that relaxed selection pressure may have led to the reduced effector coding gene content in C. purpurea species. The effector repertoire is probably highly redundant [49], and some effectors may no longer be essential since there is no genetic resistance in the host. This suggests that the broad host range is not achieved through the acquisition of a large number of unique secreted proteins.

The distribution of CAZymes categories was similar among the three Ergot pathogens analyzed. GH28, GH16 and GH28 were between the most abundant families in the three species (Additional file S11). This could suggest the importance of these families and the degradation of pectin and hemicellulose in the infection process of this species, as was previously reported [5].

\section{Predicted secreted proteins expressed in planta during Paspalum dilatatum infection}

This is the first time that RNA-seq data is reported for a C. paspali-host interaction. Although many genes may not be detected in the early stages of infection because the amount of biomass in the fungus increases over time, as does the number of sequential readings originating from the fungus, we found that most of the predicted genetic models are expressed at $1 \mathrm{dpi}$. This is probably due to the imperative need to establish early growth conditions of hyphae in the stigma and that very few sequences were detected exclusively at 4 dpi (Fig. 4). At least 326 PSP of ILB432 were expressed during first stage of infection of $P$. dilatatum cv Estanzuela Chirú. This represents about $79.7 \%$ of the total secretome. Nevertheless, no significative differences were established between expression of PSP and the full set of proteins. This could suggest that $C$. paspali requires a maximum capacity for host manipulation during intracellular colonization and that biotrophic hyphae provide a major interface for effector delivery to host cells. Expression of the predicted secretome and effectors shows the same tendencies as the whole genome where there was a higher expression at $1 \mathrm{dpi}$. As we can see after the infection has taken place (4dpi) the fungus regulates the expression of several of PSP. This unique profile expressed proteins during $1 \mathrm{dpi}$ could be important for the first stage of penetration and colonization but not for maintaining and stabilizing the infection. Even so, these results have to be taken with caution because of the absence of a basal fungal condition control like $C$. paspali axenic culture data. We cannot make claims about these genes being pathogenicity factors important for infection or if they are highly expressed housekeeping genes essential for basic biological functions. However, differences found suggest an interesting lead for pathogenicity factors recognition.

Our results, based on predictions from DNA sequence and RNA-seq analysis, show that three probable PSP and effectors have mayor FC during 1 dpi compared to 4 dpi. These three genes: CpILB432_gene 06873, CpILB432_gene 04049 and CPILB432_gene 03624 had

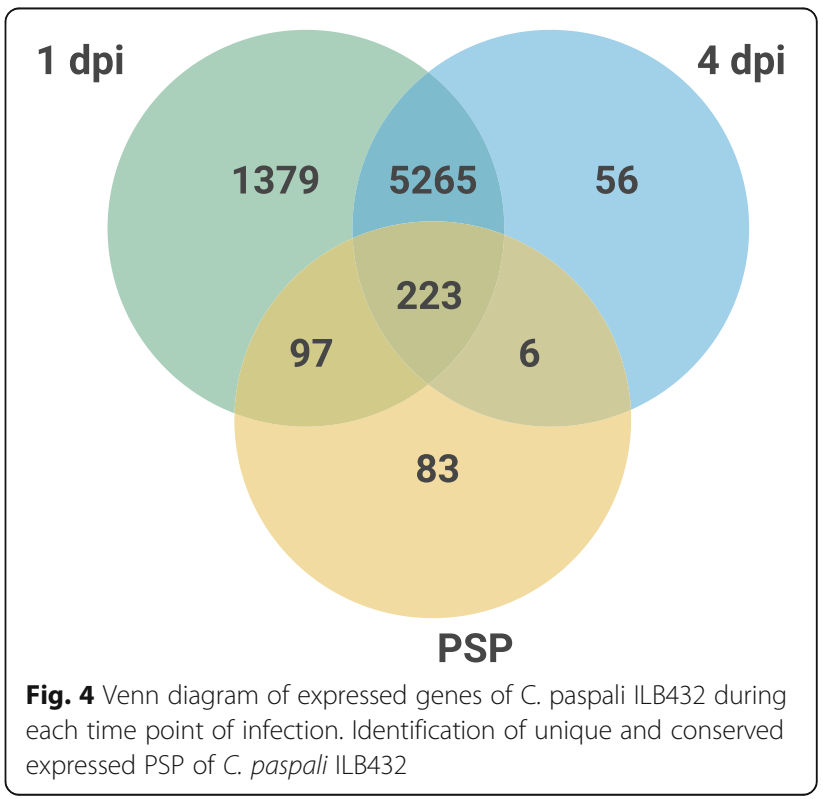


homology to three uncharacterized C. purpurea proteins. These results are similar to those obtained by Oeser [49] who found that during C. purpurea-rye interaction, the fungus expressed several effector candidates that were included in the 150 most highly expressed genes during infection, several of which did not have homology to any known proteins. Five of these even belonged to the top ten highly expressed genes. These results are also similar to our data, where 4 of the first 10 highly expressed genes in both time points evaluated were predicted as effector-like, and three of these are shared between 1 and $4 \mathrm{dpi}$. However, the role of these PSP and pathogenicity factor-like proteins in C. paspali-Paspalum pathogenesis, remains largely unanswered and further work should address this topic like knock-out stains and comparations with axenic culture RNA-seq data.

\section{Conclusions}

In this study we present an annotation for three draft genome sequences of $C$. paspali isolates that belong to two different lineages inside $C$. paspali species using a combination of RNA-seq, manual gene curation and comparative genomic techniques. The combination of genome and transcriptome sequencing allowed for datadriven gene prediction and comparative genomics with other public available genomes of Ergot disease fungal species. Our results, based on predictions from DNA sequence, showed that $C$. paspali isolates from both lineages share the main signatures and protein families in the predicted secreted proteins. The abundance of pectinolytic enzymes and the presence of chitin-degrading enzymes in the genome and secretome of $C$. paspali implies that they could be part of its pathogenic system, causing Ergot disease. The small predicted secretome size of $C$. paspali and the absence of similarity to experimentally validated effectors from other pathogens strongly suggest that $C$. paspali employs largely novel mechanisms to induce susceptibility in its host plants. This genome data and predicted secretome repertoire provides insights to design hypotheses about candidate host range determinants in the Claviceps genus and suggests details to direct biological experimentation. The analyzed genomes of C. paspali along with other Claviceps species phylogenetically closely related to each other enabled us to zoom in and further characterize secreted proteins with potential roles in the infection process.

\section{Methods}

\section{Sequence information}

For C. paspali isolates analysis (Table 6), draft genome sequence of isolate ILB432 was downloaded from NCBI Acc. GCA_013168865.1 [54] and RRC-1481 form NCBI Acc GCA_000223175.2 [94].

For identification of core predicted secretome between C. paspali and two other related species in the genus, proteins were downloaded from NCBI Acc PRJEA76493 for C. purpurea isolate 20.1 and C. fusiformis PRL1980 was downloaded from http://csbio-l.csr.uky.edu/endophyte/

\section{Isolate sampling and genome assembly}

C. paspali ILB388 isolated from P. plicatulum [52] was obtained from the "Laboratorio de Bioproducción" at INIA Las Brujas Fungal Collection (ILB). Vegetative mycelium was harvested form cultures kept in Claviceps medium [95] for 1 wk. at $26^{\circ} \mathrm{C}$. Fungal genomic DNA was extracted using Quick-DNA ${ }^{\text {tm }}$ Fungal/Bacterial Kit (Zymo Research, San Diego, USA) following the manufacturer's instructions.

For genome sequencing, DNA libraries of $500 \mathrm{bp}$ inserts were generated with TruSeq Nano DNA Kit (Illumina) and $150 \mathrm{bp}$ paired-end (PE) sequenced with Illumina HiSeq2500 platform (Illumina, San Diego, CA). was performed at Macrogen Inc., Seoul, South Korea service.

For data analysis, low quality and adapter sequences were trimmed via Trimmomatic v0.36 [96]. High quality PE were then assembled with SPAdes 3.5.0 using k-mer lengths based on read length (kmer of 21, 33 and $55 \mathrm{bp}$ for $151 \mathrm{bp}$ reads, with -careful option) [97]) and contigs shorter than $200 \mathrm{bp}$ were removed. All assemblies from C. paspali were checked with Quality Assessments Tool (QUAST 4.5, [98]) using -fungus,--split-scaffolds and - min-contig $=200$ parameters. Assembly completeness was also analyzed with Benchmarking Universal Single Copy Orthologs (BUSCO v5.0.0 [99];) using -genome mode and --augustus_parameters $=$ '--species $=$ Fusarium graminearum' and ascomycota_odb10 database.

Table 6 Information about the isolates used in this study

\begin{tabular}{lllll}
\hline Species & Isolate & Host & Protein Source & Genome reference \\
\hline C. paspali & ILB388 & P. plicatulum & This work & This work \\
C. paspali & ILB432 & P. urvillei & This work & [53] \\
C. paspali & RRC-1481 & Paspalum spp. & This work & [94] \\
C. fusiformis & PRL 1980 & Secale cereale & http://csbio-I.csr.uky.edu/endophyte/ & [94] \\
C. purpurea & 20.1 & Pennisetum typhoideum & NCBI Acc PRJEA76493 & [94] \\
\hline
\end{tabular}




\section{Claviceps paspali in planta RNA-seq data}

For RNA fungal expression analysis during infection (in planta analysis), fungal spores were collected according to Luttrell (1977) and prepared for plant inoculation according to Oeser et al. (2017). A concentration of $1 \times$ $10^{6}$ conidia/ml suspension was spread over stigmas of $P$. dilatatum plants cultivar Estanzuela Chiru one day post anthesis and incubated in a sealed, humidified tray at room temperature. Two biological replicates of the experiment were conducted in the greenhouse facility at INIA Las Brujas research station. Stigma infected samples were collected from plants at 1- and 4-days postinoculation (dpi) for RNA extraction. The criteria for the selection of the two time points was considering the phase of penetration of the fungus ( $1 \mathrm{dpi})$ and when the colonization has already taken place on the ovary (4 dpi) $[2,12]$. Each biological replicate represents a pool of 400-450 stigmas of one simple plant in order to reach RNA minimum concentration.

Samples were ground to a fine powder in a RNAsefree mortar and pestle, pre-cooled with liquid nitrogen. Total RNA was extracted using RNAeasy Plant isolation kit (Qiagen, Germany). RNA quantity and quality control were assessed using an Agilent 2100 Bioanalyzer (Agilent Technologies, Palo Alto, CA, USA). Polyadenylated mRNA was isolated from the total RNA and cDNA libraries were prepared using a Sure Select StrandSpecific RNA Library Prep mRNA kit (Illumina, San Diego, USA) following the manufacturer's instructions. Then, constructed libraries were sequenced at the $2 \times$ 150 bp PE read mode with Illumina HiSeq3000, performed at AgriBio, Centre for AgriBioscience, Melbourne, Australia. For raw RNA-seq data, Illumina adaptors and bases having a quality score value less than 25 were trimmed from both ends (final minimum size allowed after trimming of $75 \mathrm{bp}$ ) using Trimmomatic v0.36.

\section{Claviceps paspali genome gene predictions}

For C. paspali ILB388, ILB432 and RRC-1481 FunGAP pipeline [100] was used for structural annotation of genome. This pipeline uses AUGUSTUS [101], MAKER [102], and BRAKER [103] gene model prediction algorithms. Also, both in planta condition (1 and 4 dpi) RNA-seq data filtered reads were used for transcript evidence for gene predictions. A Fusarium graminearum gene model was selected for AUGUSTUS, with C. purpurea isolate 20.1 (GCA_000347355.1), Metarhizium rileyi isolate Cep018-CH2 (GCA_007866325.1) and Pochonia chlamydosporia isolate 123 (GCA 000411695.2) as sister species.

\section{Prediction of secreted proteins in Claviceps isolates}

For the determination of a probable set of secreted proteins (PSP) in the five isolates of Claviceps spp., prediction of signal peptides (SP), was carried out with Phobius web server [104] and SignalP v5 [105]. To exclude membrane proteins, the TMHMM 2.0 web server (max. 1 PredHel within first 60 amino acids) [106] was used in combination with transmembrane domain (TM) prediction by Phobius web server (no TM predicted). Note that TM domain predictions by TMHMM within the last 70 amino acid residues of the $\mathrm{N}$-terminus of a protein sequence were not considered as the tool can sometimes predict signal peptides as false-positive TM domains. To exclude sequences that have a SP but remain in the endoplasmic reticulum, all predicted secreted sequences were scanned for retention motifs from the PROSITE database (PS00014 ER_Targeting) with the ScanProsite web server [107]. Web versions of WolfPSort (organism type: fungi) [108], TargetP 2.0 [109], and ProtComp v9.0 (Softberry, USA) were used to predict the subcellular localization of sequences. The PredGPI prediction server (General model) [110] was used to predict secreted proteins that contain a GPI anchor.

At least two tools were used for inferring the presence of signal peptide, TM domain and subcellular localization, so resulting decisions were made based on the majority rule.

\section{Functional annotation of sequences}

All the predicted protein-coding genes of the three $C$. paspali isolates were functionally annotated using BLASTp [111] against the non-redundant (nr) database of the National Center of Biotechnology Information (NCBI) and classified using InterProScan v.5.19 [112]. Pfam protein families, InterPro domains, gene ontology (GO) terms classification and metabolic pathways (KEGG) were recovered from the BLAST identified proteins using Blast2GO annotation system [113]. BLASTp was made with cut-off E-value of $\leq 1 \mathrm{e}-5$. Mapping and annotation were performed on Blast2GO using default parameters.

\section{Analysis of repeats sequences}

Determination of repeat sequences could help to explain divergence and speciation in fungal genomes. For this matter, the three $C$. paspali repeated sequences present in their genome were predicted by de novo and homology-based methods following the Berriman et al. (2018) protocol. The de novo transposon libraries were constructed with the de novo software RepeatModeler (http:// repeatmasker.org/ RepeatModeler/) and LTRharvest [114]. Homology-based libraries were constructed with TransposonPSI (http:// transposonpsi.sourceforge.net). Repeat libraries were classified using RepeatClassifier (part of the RepeatModeler software) and merged using USEARCH v7 [115] to cluster the candidate sequences with $\geq 80 \%$. The genomes where then 
analyzed using this non-redundant library using RepeatMasker (http://repeatmasker.org).

Results were then used to calculate the average distance (kbp) of each gene to the closest transposable element (TE) fragment on the $5^{\prime}$ and 3' flanking side, TEs overlapping with genes were also considered as well as a distance of $0 \mathrm{kbp}$. This was performed for all the gene models and proteins of interest with customized scripts available upon request.

Statistical tests were performed with a non-parametric Mann Whitney using the mean TE closeness of PSP and all the non-PSP as control. RRC-1481 was not considered for this analysis because of the heavily partitioned available genome.

\section{Pathogenicity factors prediction pipeline}

Effector-like proteins in each isolate were identified from the predicted secreted proteins (PSP) that fulfill at least one of the following criteria previously described for classically secreted effector-like proteins in fungi by Sonah et al. [66] with some modifications: (I) small secreted proteins (SSPs), defined as those with sequence length less than or equal to 300 amino acid residues; (II) SSP with cysteine-richness (SCR). Considered cysteinerich proteins in this study are those which contain at least 4 cysteine residues and have greater than $5 \%$ of their total amino acid residues as cysteines; (III) proteins with known fungal or oomycetes effector motifs (DEER, RXLR, RXLX [EDQ], [KRHQSA][DENQ] EL, [YW] XC and RSIVEQD) that were assessed using the FIMO package in MEME program suite [116] with E-value cut-off of $\leq 1 \mathrm{e}-4$; (IV) EffectorP 2.0 [67] prediction tool was also considered for effector prediction.

Proteins with homology to known virulence/pathogenicity factor from the PHI-base (http://www.phi-base.org/ ) were also included in the set of candidates. DbCAN2 (http://cys.bios.niu.edu/dbCAN2/) was used to identify all carbohydrate-active enzymes (CAZymes) in the predicted secretome with an e-value cutoff of 10-10 using HMMER [117], Hotpep [118] and DIAMOND [119] and Plant cell wall degrading enzymes (PCWDE) were identified based on Lo Presti et al. [18].

Prediction of localization targeting of PSP after secretion was identified using ApoplastP [77] and LOCALIZER [120].

\section{Comparative analysis of orthologous gene families}

The orthologous groups among the three species, C. paspali, C. purpurea and C. fusiformis were identified with the help of OrthoFinder [121]. Orthologous gene pairs were considered based on the amino acid sequence similarity sharing up to $50 \%$ of the total length of the shorter gene being analyzed (BLASTp, threshold E-value $\leq 1 \mathrm{e}-5)$. The PSP were classified as species-specific if there was no orthologs of these proteins in the other species being considered. Also, in C. paspali isolates orthologues comparisons, the PSP were classified as isolate-specific when there were no orthologs in other C. paspali isolate. We defined core as the full set of predicted proteins belonging to orthologous groups present in all three species or isolates.

\section{RNA-seq expression analysis}

Based on the fact that the relative expression of the secreted proteins can be related to the space-time function, the quantification of gene expression was carried out. Filtered reads of both condition ( 1 and 4 dpi) were aligned to the ILB432 reference genome with STAR [122] using the previously obtained GFF3 annotation file and RSEM [123]. A statistical analysis of the expression data was performed by EdgeR [124]. The DEGs were identified using the following conditions: $-2>$ fold change $>2$ and $\operatorname{FDR}(P<0.05)$.

Clustering analysis for correlation between samples were made using PtR script of the Trinity v2.11.0 package.

\section{Abbreviations}

bp: base pair; BUSCO: Benchmarking universal single-copy orthologs; DEG: differentially expressed genes; Dpi: days post infection; ETI: effectortriggered immunity; FC: fold-change; FDR: False discovery rate; GO: Gene Ontology; kbp: kilo base pair; n/a: data not available; Nr NCBI: NCBI nonredundant protein database; PAMP: pathogen associated molecular patterns; PCWDE: plant cell wall degrading enzymes; PE: Paired-end; PSP: probable secreted proteins; PTI: PAMP-triggered immunity; SCRP: small cysteine-rich proteins; TE: Transposable element

\section{Supplementary Information}

The online version contains supplementary material available at https://doi. org/10.1186/s12864-021-08077-0.

Additional file S1. Genome annotation report of $C$. paspali isolates. Report of genome annotation of isolates ILB388 and ILB432 based on the FunGAP pipeline.

Additional file S2. Functional annotation of C. paspali isolates PSP. Functional annotation and enriched GO terms of PSP, pathogenicity factors and effector-like proteins in C. paspali isolates.

Additional file S3. Effector motif [YW] xC in proteins of C. paspali isolates. Detailed description of results based in FIMO motif search of $[\mathrm{YW}] \times \mathrm{C}$ motif in C. paspali proteins.

Additional file S4. CAZyme present in each predicted secretome of five Claviceps isolates. Detailed results of dbCAN2 search of CAZymes based on the predicted secretome of each of the five isolates of Claviceps spp. compared in this study.

Additional file S5. Closeness of coding genes in C. paspali isolates to repeated sequences. Closeness of secreted coding genes and other genes annotate to repeated sequences in genomes of $C$. paspali isolates ILB388 and ILB432

Additional file S6. Orthofinder results in C. paspali isolates. Orthofinder results based on the PSP of each $C$. paspali isolate used in this study

Additional file S7. Secretome and pathogenicity factors predicted in Claviceps spp. Summary of secretome and pathogenicity factors predicted in isolates of C. purpurea and C. fusiformis. 
Additional file S8. Orthofinder results based on Claviceps species PSP. Orthofinder results based on the PSP of C. purpurea and C. fusiformis isolates used in this study

Additional file S9. Expression results during infection process of $\mathrm{C}$. paspali in $P$. dilatatum stigma-style. Mapping results, gene ID, and expression values in TPM of all the protein coding genes present in C. paspali ILB432

Additional file S10. RNA-seq sample correlation analysis. Clustering analysis of biological replicates between conditions.

Additional file S11. Representation of CAZymes in each isolate of Claviceps analyzed in this work. Hierarchical clustering and heatmap of CAZymes families in each isolate of Claviceps.

\section{Acknowledgments}

We thank Eduardo Abreo for C. paspali ILB388 isolate and for reading the manuscript, and Fernando Lattanzi for reading the manuscript. The authors wish to acknowledge the comments of the reviewers and journal editor who contributed to the writing of the manuscript.

\section{Authors' contributions}

$\mathrm{HO}, \mathrm{MDR}$ designed experiments; $\mathrm{HO}$ and SM performed sampling, culture, DNA and RNA extractions; $\mathrm{HO}$ conducted bioinformatics analysis; RR prepared and provided the plant material; HO, MDR wrote the manuscript; $\mathrm{RR}, \mathrm{MF}, \mathrm{GS}, \mathrm{NC}$ revised the manuscript and MDR coordinated the work. All authors critically revised and approved the manuscript.

\section{Funding}

This project was supported by the National Institute of Agricultural Research of Uruguay (INIA) project BT-19, and by project ATN/KF-13883-UR from the Inter-American Development Bank. HO Scholarship was founded by through the INIA Postgraduate Scholarship Program. The funding bodies played no role in the design of the study and collection, analysis, and interpretation of data and in writing the manuscript.

\section{Availability of data and materials}

The genomic sequences and RNA-seq datasets generated during the current study are available at NCBI BioProject repository, under accession number PRJNA625338. Genomic sequences from ILB432 can be accessed from NCB Acc. GCA 013168865.1, ILB388 from NCBI ACC GCA 000223175.2 and RRC1481 from NCBI ACC GCA_000223175.2. C. purpurea 20.1 and C. fusiformis PRL1980 protein datasets were download from NCBI AcC PRJEA76493 and http://csbio-I.csr.uky.edu/endophyte/ respectively. Structural and functional annotations of $C$. paspali isolates obtained in this study are available from the corresponding author upon reasonable request.

\section{Declarations}

\section{Ethics approval and consent to participate}

Not applicable.

\section{Consent for publication}

Not applicable.

\section{Competing interests}

The authors declare that they have no competing interests.

\section{Author details}

${ }^{1}$ Instituto Nacional de Investigación Agropecuaria (INIA). Unidad de Biotecnología. Estación Experimental INIA Las Brujas, Ruta 48 km, 10 Canelones, Uruguay. ${ }^{2}$ Agriculture Victoria, AgriBio, Centre for AgriBioscience, 5 Ring Road, Bundoora, VIC 3083, Australia. ${ }^{3}$ School of Applied Systems Biology, La Trobe University, 5 Ring Road, Bundoora, VIC 3083, Australia. ${ }^{4}$ Instituto Nacional de Investigación Agropecuaria (INIA). Programa Pasturas y Forrajes. Estación Experimental INIA Tacuarembó, Ruta 5 km, 386 Tacuarembó, Uruguay. ${ }^{5}$ Centro Universitario Regional del Este (CURE), Polo de Desarrollo Universitario: Patogenicidad, toxicidad y genética en los ecosistemas pastoriles de la región Este de Uruguay, Ruta 8 km, 281 Treinta y Tres, Uruguay.
Received: 24 September 2020 Accepted: 11 October 2021

Published online: 26 October 2021

\section{References}

1. Píchová K, Pažoutová S, Kostovčík M, Chudíčková M, Stodůlková E, Novák P, et al. Evolutionary history of ergot with a new infrageneric classification (Hypocreales: Clavicipitaceae: Claviceps). Mol Phylogenet Evol. 2018;123 February:73-87. doi:https://doi.org/10.1016/j.ympev.2018.02.013.

2. Luttrell ES. The disease cycle and fungus-host relationships in dallisgrass ergot. Phytopathology. 1977;67(12):1461-8. https://doi.org/10.1094/Phyto67-1461.

3. Brown HB. Life history and poisonous properties of Claviceps Paspali. J Agric Res. 1916:7:401-7.

4. Alderman SC, Halse RR, White JF. A reevaluation of the host range and geographical distribution of Claviceps species in the United States. Plant Dis. 2004;88(1):63-81. https://doi.org/10.1094/PDIS.2004.88.1.63.

5. Tudzynski P, Scheffer J. Claviceps purpurea: molecular aspects of a unique pathogenic lifestyle. Mol Plant Pathol. 2004;5(5):377-88. https://doi.org/1 0.1111/j.1364-3703.2004.00237.x.

6. Acuña CA, Martínez EJ, Zilli AL, Brugnoli EA, Espinoza F, Marcón F, et al. Reproductive Systems in Paspalum : Relevance for Germplasm Collection and Conservation, Breeding Techniques, and Adoption of Released Cultivars. Front Plant Sci. 2019;10 November:1-17. doi: https://doi.org/10.33 89/fpls.2019.01377

7. Speranza P, Viega L, Gutierrez L, Astigarraga L, Picasso V, Saldanha S, et al. Utilización y domesticación de gramíneas forrajeras del género Paspalum en Uruguay. 2017; March 2018:61. http://www.ainfo.inia.uy/digital/bitstream/ item/8260/1/Fpta-61-2017.pdf.

8. Couso LL, Gatti ML, Cornaglia PS, Schrauf GE, Fernández RJ. Are more productive varieties of Paspalum dilatatum less tolerant to drought? Grass Forage Sci. 2010;65:296-303. https://doi.org/10.1111/j.1365-2494.2010.00748.x

9. Carambula M. Pasturas y forrajes; potenciales y alternativas para producir forraje. Hemisferio Sur: Montevideo; 2007.

10. Kozák L, Szilágyi Z, Vágó B, Kakuk A, Tóth L. Inactivation of the indolediterpene biosynthetic gene cluster of Claviceps paspali by Agrobacterium -mediated gene replacement. Appl Microbiol Biotechnol. 2018:0-3.

11. Coufal-Majewski S, Stanford K, McAllister T, Blakley B, McKinnon J, Chaves AV, et al. Impacts of Cereal Ergot in Food Animal Production. Front Vet Sci. 2016:3 February. doi:https://doi.org/10.3389/fvets.2016.00015.

12. Esposito R., Lopez C. Caracteristicas biológicas de Claviceps paspali Stev. and Hall. Bol Micológico. 2001;16:1-8.

13. Pizarro EA. Potencial forrajero del género Paspalum. Pasturas tropicales. 2002:22:38-46.

14. Schrauf GE, Blanco M, Cornaglia PS, Deregibus V, Madia M, MG PACHECO, et al. Ergot resistance in plants of Paspalum dilatatum incorporated by hybridisation with Paspalum urvillei. Trop Grasslands. 2003;37:182-6.

15. Miedaner T, Geiger HH. Biology, genetics, and management of ergot (Claviceps spp.) in rye, sorghum, and pearl millet. Toxins (Basel). 2015;7(3): 659-78. https://doi.org/10.3390/toxins7030659.

16. Rios E, Blount A, Harmon P, Mackowiak C, Kenworthy K, Quesenberry K. Ergot resistant tetraploid bahiagrass and fungicide effects on seed yield and quality. Plant Heal Prog. 2015;16(2):56-62. https://doi.org/10.1094/PHPRS-14-0051.

17. Boutrot F, Zipfel C. Function, discovery, and exploitation of plant pattern recognition receptors for broad-Spectrum disease resistance. Annu Rev Phytopathol. 2017:55(1):257-86. https://doi.org/10.1146/annurev-phyto080614-120106.

18. Lo Presti L, Lanver D, Schweizer G, Tanaka S, Liang L, Tollot M, et al. Fungal effectors and plant susceptibility. Annu Rev Plant Biol. 2015;66(1):513-45. https://doi.org/10.1146/annurev-arplant-043014-114623.

19. Põlme $S$, Bahram $M$, Jacquemyn $H$, Kennedy $P$, Kohout $P$, Moora $M$, et al. Host preference and network properties in biotrophic plantfungal associations. New Phytol. 2018;217(3):1230-9. https://doi.org/1 $0.1111 /$ nph. 14895

20. Kubicek CP, Starr TL, Glass NL. Plant Cell Wall-degrading enzymes and their secretion in plant-pathogenic Fungi. Annu Rev Phytopathol. 2014;52(1):42751. https://doi.org/10.1146/annurev-phyto-102313-045831.

21. Ah-fong AMW, Shrivastava J, Judelson HS. Lifestyle, gene gain and loss, and transcriptional remodeling cause divergence in the transcriptomes of Phytophthora infestans and Pythium ultimum during potato tuber 
colonization. BMC Genomics. 2017;18(1):1-28. https://doi.org/10.1186/s12 864-017-4151-2.

22. Krijger J-JJ, Thon MR, Deising HB, SGGRG W. Compositions of fungal secretomes indicate a greater impact of phylogenetic history than lifestyle adaptation. BMC Genomics. 2014;15(1):722. https://doi.org/10.1186/1471-21 64-15-722.

23. Hinsch J, Galuszka P, Tudzynski P. Functional characterization of the first filamentous fungal tRNA-isopentenyltransferase and its role in the virulence of Claviceps purpurea. New Phytol. 2016;211(3):980-92. https://doi.org/1 $0.1111 /$ nph. 13960.

24. Wang A, Pan L, Niu X, Shu X, Yi X, Yamamoto N, et al. Comparative secretome analysis of different smut fungi and identification of plant cell death-inducing secreted proteins from Tilletia horrida. BMC Plant Biol. 2019; 19(1):1-14. https://doi.org/10.1186/s12870-019-1924-6.

25. Sánchez-Vallet A, Mesters JR, Thomma BPHJ. The battle for chitin recognition in plant-microbe interactions. FEMS Microbiol Rev. 2015;39(2): 171-83. https://doi.org/10.1093/femsre/fuu003.

26. Vincent $D$, Rafiqi M, Job D. The Multiple Facets of Plant-Fungal Interactions Revealed Through Plant and Fungal Secretomics. Front Plant Sci. 2020;10 January. doi:https://doi.org/10.3389/fpls.2019.01626.

27. Nejat N, Rookes J, Mantri NL, Cahill DM. Plant-pathogen interactions: toward development of next-generation disease-resistant plants. Crit Rev Biotechnol. 2017:37(2):229-37. https:/doi.org/10.3109/07388551.2015.1134437.

28. Toruño TY, Stergiopoulos I, Coaker G. Plant-pathogen effectors: cellular probes interfering with plant defenses in spatial and temporal manners. Annu Rev Phytopathol. 2016;54(1):419-41. https://doi.org/10.1146/annurevphyto-080615-100204.

29. Franceschetti M, Maqbool A, Pennington HG, Kamoun S, Banfield MJ, Jiménez-Dalmaroni MJ, et al. Effectors of filamentous plant pathogens: commonalities amid diversity. Microbiol Mol Biol Rev. 2017;81(2):1-17. https://doi.org/10.1128/MMBR.00066-16.

30. Kretschmer M, Damoo D, Djamei A, Kronstad J. Chloroplasts and plant immunity: where are the fungal effectors? Pathogens. 2019;9(1):19. https:// doi.org/10.3390/pathogens9010019.

31. Neu E, Debener T. Prediction of the Diplocarpon rosae secretome reveals candidate genes for effectors and virulence factors. Fungal Biol. 2019;123(3): 231-9. https://doi.org/10.1016/j.funbio.2018.12.003.

32. Mentlak TA, Kombrink A, Shinya T, Ryder LS, Otomo I, Saitoh H, et al. Effector-mediated suppression of chitin-triggered immunity by Magnaporthe oryzae is necessary for rice blast disease. Plant Cell. 2012;24(1): 322-35. https://doi.org/10.1105/tpc.111.092957.

33. de Jonge R, Peter van Esse $H$, Kombrink A, Shinya T, Desaki $Y$, Bours $R$, et al. Conserved Fungal LysM Effector Ecp6 Prevents Chitin-Triggered Immunity in Plants. Science. 2010;329(80):953-5. https://doi.org/10.1126/science.11 90859.

34. Thomma BPHJ, Nürnberger T, Joosten MHAJ. Of PAMPs and effectors: the blurred PTI-ETI dichotomy. Plant Cell. 2011;23(1):4-15. https://doi.org/10.11 05/tpc.110.082602.

35. Oliveira-Garcia E, Valent B. How eukaryotic filamentous pathogens evade plant recognition. Elsevier Ltd. 2015;26:92-101. https://doi.org/10.1016/j. mib.2015.06.012

36. Pelgrom AJE, Van den Ackerveken G. Microbial Pathogen Effectors in Plant Disease. eLS. 2016; August:1-10.

37. Bent AF, Mackey D. Elicitors, effectors, and R genes: the new paradigm and a lifetime supply of questions. Annu Rev Phytopathol. 2008;45:399-436.

38. Pažoutová S, Pešicová K, Chudíčková M, Šrưtka P, Kolařík M. Delimitation of cryptic species inside Claviceps purpurea. Fungal Biol. 2015;119(1):7-26. https://doi.org/10.1016/j.funbio.2014.10.003.

39. Derbyshire M, Denton-Giles M, Hegedus D, Seifbarghi S, Rollins J, Van Kan J, et al. The complete genome sequence of the phytopathogenic fungus Sclerotinia sclerotiorum reveals insights into the genome architecture of broad host range pathogens. Genome Biol Evol. 2017;9(3):593-618. https:// doi.org/10.1093/gbe/evx030.

40. Brown NA, Antoniw J, Hammond-kosack KE. The predicted secretome of the plant pathogenic fungus fusarium graminearum: a refined comparative analysis. PLoS One. 2012;7(4). https://doi.org/10.1371/journal.pone.0033731.

41. Li T, Wu Y, Wang Y, Gao H, Gupta VK, Duan X, et al. Secretome profiling reveals virulence-associated proteins of fusarium proliferatum during interaction with banana fruit. Biomolecules. 2019;9(6). https://doi.org/10.33 90/biom9060246.
42. Valero-Jiménez CA, Veloso J, Staats M, Van Kan JAL, Van Kan JAL, Van Kan JAL. Comparative genomics of plant pathogenic Botrytis species with distinct host specificity. BMC Genomics. 2019;20(1):1-12. https://doi.org/1 0.1186/s12864-019-5580-x.

43. Heard S, Brown NA, Hammond-Kosack K. An interspecies comparative analysis of the predicted secretomes of the necrotrophic plant pathogens sclerotinia sclerotiorum and botrytis Cinerea. PLoS One. 2015;10(6):1-27. https://doi.org/10.1371/journal.pone.0130534.

44. Anderson JP, Sperschneider J, Win J, Kidd B, Yoshida K, Hane J, et al. Comparative secretome analysis of Rhizoctonia solani isolates with different host ranges reveals unique secretomes and cell death inducing effectors. Sci Rep. 2017;7(1):1-13. https://doi.org/10.1038/s41598-017-10405-y.

45. Oeser B, Heidrich PM, Müller U, Tudzynski P, Tenberge KB. Polygalacturonase is a pathogenicity factor in the Claviceps purpurea/rye interaction. Fungal Genet Biol. 2002;36(3):176-86. https://doi.org/10.1016/S1087-1845(02)00020-8.

46. Nathues E, Joshi S, Tenberge KB, Von Den Driesch M, Oeser B, Bäumer N, et al. CPTF1, a CREB-like transcription factor, is involved in the oxidative stress response in the phytopathogen Claviceps purpurea and modulates ROS level in its host Secale cereale. Mol Plant-Microbe Interact. 2004;17(4): 383-93. https://doi.org/10.1094/MPMl.2004.17.4.383.

47. Mey G, Held K, Scheffer J, Tenberge KB, Tudzynski P. CPMK2, an SLT2homologous mitogen-activated protein (MAP) kinase, is essential for pathogenesis of Claviceps purpurea on rye: evidence for a second conserved pathogenesis-related MAP kinase cascade in phytopathogenic fungi. Mol Biol. 2002;46(2):305-18. https://doi.org/10.1046/j.1365-2958.2002. 03133.X.

48. Hinsch J, Vrabka J, Oeser B, Novák O, Galuszka P, Tudzynski P. De novo biosynthesis of cytokinins in the biotrophic fungus Claviceps purpurea. Environ Microbiol. 2015;17(8):2935-51. https://doi.org/10.1111/1462-2920.12838.

49. Oeser B, Kind S, Schurack S, Schmutzer T, Tudzynski P, Hinsch J. Cross-talk of the biotrophic pathogen Claviceps purpurea and its host Secale cereale. BMC Genomics. 2017;18(1):273. https://doi.org/10.1186/s12864-017-3619-4.

50. Kind S, Hinsch J, Vrabka J, Hradilová M, Majeská-Čudejková M, Tudzynski P, et al. Manipulation of cytokinin level in the ergot fungus Claviceps purpurea emphasizes its contribution to virulence. Curr Genet. 2018;64(6):1303-19. https://doi.org/10.1007/s00294-018-0847-3.

51. Xia C, Wang M, Cornejo OE, Jiwan DA, See DR, Chen X. Secretome characterization and correlation analysis reveal putative pathogenicity mechanisms and identify candidate avirulence genes in the wheat stripe rust Fungus Puccinia striiformis f. sp. tritici. Front Microbiol. 2017;8 DEC.

52. Oberti H, Dalla-Rizza MD, Reyno R, Murchio S, Altier N, Abreo E, et al. Diversity of Claviceps paspali reveals unknown lineages and unique alkaloid genotypes. Mycologia. 2020;112(2):230-43. https://doi.org/10.1080/002 75514.2019.1694827.

53. Oberti H, Abreo E, Reyno R, Feijoo M, Murchio S, Dalla-Rizza M. New draft genome sequence of the ergot disease fungus Claviceps paspali. Microbiol Resour Announc. 2020;9(29):1-3. https://doi.org/10.1128/MRA.00498-20.

54. Schardl CL, Young CA, Hesse U, Amyotte SG, Andreeva K, Calie PJ, et al. Plant-symbiotic Fungi as chemical engineers: multi-genome analysis of the Clavicipitaceae reveals dynamics of alkaloid loci. PLoS Genet. 2013;9(2): e1003323. https://doi.org/10.1371/journal.pgen.1003323.

55. Min XJ. Evaluation of computational methods for secreted protein prediction in different eukaryotes. J Proteomics Bioinforma. 2010;3:143-7.

56. Urban M, Cuzick A, Seager J, Wood V, Rutherford K, Venkatesh SY, et al. PHIbase: the pathogen-host interactions database. Nucleic Acids Res. 2020; 48(D1):D613-20. https://doi.org/10.1093/nar/gkz904.

57. Asmann YW, Klee EW, Thompson EA, Perez EA, Middha S, Oberg AL, et al. 3' tag digital gene expression profiling of human brain and universal reference RNA using Illumina genome analyzer. BMC Genomics. 2009;10(1): 531. https://doi.org/10.1186/1471-2164-10-531.

58. Griffith M, Griffith OL, Mwenifumbo J, Goya R, Morrissy AS, Morin RD, et al. Alternative expression analysis by RNA sequencing. Nat Methods. 2010;7(10): 843-7. https://doi.org/10.1038/nmeth.1503.

59. Wu AR, Neff NF, Kalisky T, Dalerba P, Treutlein B, Rothenberg ME, et al. Quantitative assessment of single-cell RNA-sequencing methods. Nat Methods. 2014;1 1(1):41-6. https://doi.org/10.1038/nmeth.2694.

60. Shi Y, He M. Differential gene expression identified by RNA-Seq and qPCR in two sizes of pearl oyster (Pinctada fucata). Gene. 2014;538(2):313-22. https:// doi.org/10.1016/j.gene.2014.01.031.

61. Iwanicki NSA, Delalibera I, Eilenberg J, de Fine Licht HH. Comparative RNAseq analysis of the insect-pathogenic fungus metarhizium anisopliae 
reveals specific transcriptome signatures of filamentous and yeast-like development. G3 genes, genomes. Genet. 2020;10(7):2141-57. https://doi. org/10.1534/g3.120.401040.

62. Aylward J, Steenkamp ET, Dreyer LL, Roets F, Wingfield BD, Wingfield MJ. A plant pathology perspective of fungal genome sequencing. IMA Fungus. 2017;8(1):1-15. https://doi.org/10.5598/imafungus.2017.08.01.01.

63. Rao S, Sharda S, Oddi V, Nandineni MR. The landscape of repetitive elements in the refined genome of chilli anthracnose fungus colletotrichum truncatum. Front Microbiol. 2018;9 OCT:1-19.

64. Everhart S, Gambhir N, Stam R. Population Genomics of Filamentous Plant Pathogens-A Brief Overview of Research Questions, Approaches, and Pitfalls. Phytopathology ${ }^{\oplus}$. 2020;:PHYTO-11-20-052.

65. Macho AP. Subversion of plant cellular functions by bacterial type-III effectors: beyond suppression of immunity. New Phytol. 2016;210(1):51-7. https://doi.org/10.1111/nph.13605.

66. Sonah H, Deshmukh RK, Bélanger RR. Computational prediction of effector proteins in fungi: opportunities and challenges. Front Plant Sci. 2016;7:1-14. https://doi.org/10.3389/fpls.2016.00126.

67. Sperschneider J, Dodds PN, Gardiner DM, Singh KB, Taylor JM. Improved prediction of fungal effector proteins from secretomes with EffectorP 2.0. Mol Plant Pathol. 2018;19:2094-110.

68. Lowe RGTT, Howlett BJ. Indifferent, affectionate, or deceitful: lifestyles and secretomes of fungi. PLoS Pathog. 2012;8:1-3.

69. Meinken J, Asch DK, Neizer-Ashun KA, Chang G-H, R. Cooper JR C, Min XJ. FunSecKB2: a fungal protein subcellular location knowledgebase. Comput Mol Biol. 2014;4:1-17. https://doi.org/10.5376/cmb.2014.04.0007.

70. Kim KT, Jeon J, Choi J, Cheong K, Song H, Choi G, et al. Kingdom-wide analysis of fungal small secreted proteins (SSPS) reveals their potential role in host association. Front Plant Sci. 2016;7:1-13. https://doi.org/10.3389/ fpls.2016.00186.

71. Ökmen B, Mathow D, Hof A, Lahrmann U, Aßmann D, Doehlemann G, et al. Mining the effector repertoire of the biotrophic fungal pathogen Ustilago hordei during host and non-host infection. Mol Plant Pathol. 2018;19(12): 2603-22. https://doi.org/10.1111/mpp.12732.

72. Rep M. Small proteins of plant-pathogenic fungi secreted during host colonization. FEMS Microbiol Lett. 2005;253(1):19-27. https://doi.org/10.101 6/j.femsle.2005.09.014.

73. Jain M, Srivastava PL, Verma M, Ghangal R, Garg R. De novo transcriptome assembly and comprehensive expression profiling in Crocus sativus to gain insights into apocarotenoid biosynthesis. Sci Rep. 2016;6 March:1-13. doi: https://doi.org/10.1038/srep22456.

74. Wyka SA, Mondo SJ, Liu M, Dettman J, Nalam V, Broders KD. Whole-genome comparisons of ergot Fungi reveals the divergence and evolution of species within the genus Claviceps are the result of varying mechanisms driving genome evolution and host range expansion. Genome Biol Evol. 2021;13(2): 1-21. https://doi.org/10.1093/gbe/evaa267.

75. Mey G, Correia T, Oeser B, Kershaw MJ, Garre V, Arntz C, et al. Structural and functional analysis of an oligomeric hydrophobin gene from Claviceps purpurea. Mol Plant Pathol. 2003;4(1):31-41. https://doi.org/10.1046/j.1364-3 703.2003.00138.x.

76. Stotz HU, Mitrousia GK, De Wit PJGM, Fitt BDLL, de Wit PJGM, Fitt BDLL, et al. Effector-triggered defence against apoplastic fungal pathogens. Trends Plant Sci. 2014;19(8):491-500. https://doi.org/10.1016/j.tplants.2014.04.009.

77. Sperschneider J, Dodds PN, Singh KB, Taylor JM. ApoplastP: prediction of effectors and plant proteins in the apoplast using machine learning. New Phytol. 2018;217(4):1764-78. https://doi.org/10.1111/nph.14946.

78. Kazan K, Lyons R. Intervention of Phytohormone pathways by pathogen effectors. Plant Cell. 2014;26(6):2285-309. https://doi.org/10.1105/tpc.114.12 5419.

79. Lo Presti L, Kahmann R. How filamentous plant pathogen effectors are translocated to host cells. Curr Opin Plant Biol. 2017;38:19-24. https://doi. org/10.1016/j.pbi.2017.04.005.

80. Rodriguez-Moreno L, Ebert MK, Bolton MD, Thomma BPHJHJ. Tools of the crook- infection strategies of fungal plant pathogens. Plant J. 2018;93(4): 664-74. https://doi.org/10.1111/tpj.13810.

81. Godfrey D, Böhlenius H, Pedersen C, Zhang Z, Emmersen J, ThordalChristensen $\mathrm{H}$. Powdery mildew fungal effector candidates share $\mathrm{N}$-terminal Y/F/WxC-motif. BMC Genomics. 2010;11(1):317. https://doi.org/10.1186/14 71-2164-11-317.

82. Duplessis S, Cuomo CA, Lin YC, Aerts A, Tisserant E, Veneault-Fourrey C, et al. Obligate biotrophy features unraveled by the genomic analysis of rust fungi. Proc Natl Acad Sci U S A. 2011;108(22):9166-71. https://doi.org/10.1 073/pnas.1019315108.

83. Dubey M, Vélëz H, Broberg M, Jensen DF, Karlsson M. LysM Proteins Regulate Fungal Development and Contribute to Hyphal Protection and Biocontrol Traits in Clonostachys rosea. Front Microbiol. 2020;11 April:1-19. doi:https://doi.org/10.3389/fmicb.2020.00679

84. Glass NL, Schmoll M, Cate JHDD, Coradetti S. Plant Cell Wall deconstruction by ascomycete Fungi. Annu Rev Microbiol. 2013;67(1):477-98. https://doi. org/10.1146/annurev-micro-092611-150044.

85. Janni M, Sella L, Favaron F, Blechl AE, De Lorenzo G, Ovidio RD, et al. The expression of a bean PGIP in transgenic wheat confers increased resistance to the fungal pathogen Bipolaris sorokiniana. Mol Plant-Microbe Interact. 2008;21(2):171-7. https://doi.org/10.1094/MPMI-21-2-0171.

86. Ferrari S, Sella L, Janni M, De Lorenzo G, Favaron F, Ovidio RD, et al. Transgenic expression of polygalacturonase-inhibiting proteins in Arabidopsis and wheat increases resistance to the flower pathogen fusarium graminearum. Plant Biol. 2012;14(SUPPL. 1):31-8. https://doi.org/1 0.1111/j.1438-8677.2011.00449.x.

87. Pressey R, Reger BJ. Polygalacturonase in pollen from corn and other grasses. Plant Sci. 1989;59(1):57-62. https://doi.org/10.1016/0168-9452 (89)90008-3.

88. Valette-Collet O, Cimerman A, Reignault P, Levis C, Boccara M. Disruption of Botrytis cinerea pectin methylesterase gene Bcpme1 reduces virulence on several host plants. Mol Plant-Microbe Interact. 2003;16(4):360-7. https://doi. org/10.1094/MPMI.2003.16.4.360.

89. Pusztahelyi T. Chitin and chitin-related compounds in plant-fungal interactions. Mycology. 2018;9(3):189-201. https://doi.org/10.1080/215012 03.2018.1473299.

90. Tenberge KB. Biology and life strategy of the ergot fungi. Med Aromat Plants - Ind Profiles. 1999:25-56.

91. Lorenz N, Wilson EV, Machado C, Schardl CL, Tudzynski P. Comparison of ergot alkaloid biosynthesis gene clusters in Claviceps species indicates loss of late pathway steps in evolution of C. fusiformis. Appl Environ Microbiol. 2007;73(22):7185-91. https://doi.org/10.1128/AEM.01040-07.

92. Benevenuto J, Teixeira-Silva NS, Kuramae EE, Croll D, Monteiro-Vitorello CB. Comparative Genomics of Smut Pathogens: Insights From Orphans and Positively Selected Genes Into Host Specialization. Front Microbiol. 2018;9 APR:1-17. doi:https://doi.org/10.3389/fmicb.2018.00660.

93. Beckerson WC, Rodríguez De La Vega RC, Hartmann FE, Duhamel M, Giraud T, Perlin MH. Cause and effectors: Whole-genome comparisons reveal shared but rapidly evolving effector sets among host-specific plant-castrating fungi. MBio. 2019;10(6):1-17. https://doi.org/10.1128/mBio.02391-19.

94. Tscherter $\mathrm{H}$, Hauth $\mathrm{H}$. Three new ergot alkaloids from saprophytic culture of Claviceps paspali Stevens et hall. Helv Chim Acta. 1974;57(1):113-21. https:// doi.org/10.1002/hlca.19740570111.

95. Gilmore BS, Alderman SC, Knaus BJ, Bassil NV, Martin RC, Dombrowski JE, et al. Simple sequence repeat markers that identify Claviceps species and strains. Fungal Biol Biotechnol. 2016;3(1):1-13. https://doi.org/10.1186/s4 0694-016-0019-5.

96. Bolger AM, Lohse M, Usadel B. Trimmomatic: a flexible trimmer for Illumina sequence data. Bioinformatics. 2014;30(15):2114-20. https://doi.org/10.1093/ bioinformatics/btu170.

97. Bankevich A, Nurk S, Antipov D, Gurevich AA, Dvorkin M, Kulikov AS, et al. SPAdes: a new genome assembly algorithm and its applications to singlecell sequencing. J Comput Biol. 2012;19(5):455-77. https://doi.org/10.1089/ cmb.2012.0021.

98. Gurevich A, Saveliev V, Vyahhi N, Tesler G. QUAST: quality assessment tool for genome assemblies. Bioinformatics. 2013;29(8):1072-5. https://doi.org/ 0.1093/bioinformatics/btt086.

99. Simão FA, Waterhouse RM, loannidis P, Kriventseva EV. BUSCO : assessing genome assembly and annotation complete- ness with single-copy orthologs. Bioinforma Adv. 2015:9-10.

100. Min B, Grigoriev IV, Choi IG. FunGAP: Fungal Genome Annotation Pipeline using evidence-based gene model evaluation. Bioinformatics. 2017:33(18): 2936-7. https://doi.org/10.1093/bioinformatics/btx353.

101. Hoff KJ, Stanke M. WebAUGUSTUS--a web service for training AUGUSTUS and predicting genes in eukaryotes. Nucleic Acids Res. 2013;41 Web Server issue:123-128.

102. Holt C, Yandell M. MAKER2: an annotation pipeline and genome-database management tool for second-generation genome projects. BMC Bioinformatics. 2011;12(1). https://doi.org/10.1186/1471-2105-12-491. 
103. Hoff KJ, Lange S, Lomsadze A, Borodovsky M, Stanke M. BRAKER1: unsupervised RNA-Seq-based genome annotation with GeneMark-ET and AUGUSTUS. Bioinformatics. 2016;32(5):767-9. https://doi.org/10.1093/ bioinformatics/btv661.

104. Käll L, Krogh A, Sonnhammer ELLL, Ka L. Advantages of combined transmembrane topology and signal peptide prediction-the Phobius web server. Nucleic Acids Res. 2007;35(SUPPL.2):429-32. https://doi.org/10.1093/ nar/gkm256.

105. Almagro Armenteros JJ, Tsirigos KD, Sønderby CK, Petersen TN, Winther O, Brunak S, et al. SignalP 5.0 improves signal peptide predictions using deep neural networks. Nat Biotechnol. 2019;37(4):420-3. https://doi.org/10.1038/ s41587-019-0036-z.

106. Krogh A, Larsson B, Von Heijne G, Sonnhammer ELLL, Larsson Ė, Von Heijne $\mathrm{G}$, et al. Predicting transmembrane protein topology with a hidden Markov model: application to complete genomes. J Mol Biol. 2001;305(3):567-80. https://doi.org/10.1006/jmbi.2000.4315.

107. de Castro E, Sigrist CJA, Gattiker A, Bulliard V, Langendijk-Genevaux PS, Gasteiger E, et al. ScanProsite: Detection of PROSITE signature matches and ProRule-associated functional and structural residues in proteins. Nucleic Acids Res. 2006;34 WEB. SERV. ISS:362-365.

108. Horton P, Park KJ, Obayashi T, Fujita N, Harada H, Adams-Collier CJ, et al WoLF PSORT: protein localization predictor. Nucleic Acids Res. 2007; 35(SUPPL.2):585-7. https://doi.org/10.1093/nar/gkm259.

109. Armenteros JJA, Salvatore M, Emanuelsson O, Winther O, Von Heijne G, Elofsson A, et al. Detecting sequence signals in targeting peptides using deep learning. Life Sci Alliance. 2019;2(5):1-14. https://doi.org/10.26508/lsa.2 01900429.

110. Pierleoni A, Martelli P, Casadio R. PredGPI: a GPI-anchor predictor. BMC Bioinformatics. 2008;9(1):1-11. https://doi.org/10.1186/1471-2105-9-392.

111. Camacho C, Coulouris G, Avagyan V, Ma N, Papadopoulos J, Bealer K, et al. BLAST+: architecture and applications. BMC Bioinformatics. 2009;10(1):1-9. https://doi.org/10.1186/1471-2105-10-421.

112. Jones P, Binns D, Chang HY, Fraser M, Li W, MCAnulla C, et al. InterProScan 5: genome-scale protein function classification. Bioinformatics. 2014;30(9): 1236-40. https://doi.org/10.1093/bioinformatics/btu031.

113. Götz S, García-Gómez JM, Terol J, Williams TD, Nagaraj SH, Nueda MJ, et al. High-throughput functional annotation and data mining with the Blast2GO suite. Nucleic Acids Res. 2008;36(10):3420-35. https://doi.org/10.1093/nar/gkn176.

114. Ellinghaus D, Kurtz S, Willhoeft U. LTRharvest, an efficient and flexible software for de novo detection of LTR retrotransposons. BMC Bioinformatics. 2008;9(1). https://doi.org/10.1186/1471-2105-9-18.

115. Edgar RC. Search and clustering orders of magnitude faster than BLAST. Bioinformatics. 2010;26(19):2460-1. https:/doi.org/10.1093/bioinformatics/btq461.

116. Grant CE, Bailey TL, Noble WS. FIMO: scanning for occurrences of a given motif. Bioinformatics. 2011;27(7):1017-8. https://doi.org/10.1093/bioinforma tics/btr064.

117. Finn RD, Clements J, Eddy SR. HMMER web server: interactive sequence similarity searching. Nucleic Acids Res. 2011;39(SUPPL. 2):29-37. https://doi. org/10.1093/nar/gkr367.

118. Busk PK, Pilgaard B, Lezyk MJ, Meyer AS, Lange L. Homology to peptide pattern for annotation of carbohydrate-active enzymes and prediction of function. BMC Bioinformatics. 2017;18(1):1-9. https://doi.org/10.1186/s12859017-1625-9.

119. Buchfink $B$, Xie C, Huson DH. Fast and sensitive protein alignment using DIAMOND. Nat Methods. 2014;12(1):59-60. https://doi.org/10.1038/nmeth.3176.

120. Sperschneider J, Catanzariti AM, Deboer K, Petre B, Gardiner DM, Singh KB, et al. LOCALIZER: Subcellular localization prediction of both plant and effector proteins in the plant cell. Sci Rep. 2017;7 February:1-14. doi:https:// doi.org/10.1038/srep44598.

121. Emms DM, Kelly S. OrthoFinder: phylogenetic orthology inference for comparative genomics. Genome Biol. 2019;20:1-14.

122. Dobin A, Gingeras TR, Spring C, Flores R, Sampson J, Knight R, et al. Mapping RNA-seq with STAR. Curr Protoc Bioinforma. 2016;51(1):586-97. https://doi.org/10.1002/0471250953.bi1114s51.

123. Li B, Dewey CN. RSEM: accurate transcript quantification from RNA-seq data with or without a reference genome. BMC Bioinformatcs 2011,12:323. doi: https://doi.org/10.1186/1471-2105-12-323:41-74

124. Robinson MD, McCarthy DJ, Smyth GK. edgeR: a Bioconductor package for differential expression analysis of digital gene expression data. Bioinformatics. 2009;26(1):139-40. https://doi.org/10.1093/bioinformatics/ btp616.

\section{Publisher's Note}

Springer Nature remains neutral with regard to jurisdictional claims in published maps and institutional affiliations.
Ready to submit your research? Choose BMC and benefit from:

- fast, convenient online submission

- thorough peer review by experienced researchers in your field

- rapid publication on acceptance

- support for research data, including large and complex data types

- gold Open Access which fosters wider collaboration and increased citations

- maximum visibility for your research: over $100 \mathrm{M}$ website views per year

At $\mathrm{BMC}$, research is always in progress.

Learn more biomedcentral.com/submissions 